\title{
'Not birth, marriage or death, but gastrulation': the life of a quotation in biology
}

\author{
Nick Hopwood* \\ Department of History and Philosophy of Science, University of Cambridge \\ *Corresponding author: Nick Hopwood, Email: ndh12@cam.ac.uk
}

\begin{abstract}
This history of a statement attributed to the developmental biologist Lewis Wolpert exemplifies the making and uses of quotations in recent science. Wolpert's dictum, 'It is not birth, marriage or death, but gastrulation which is truly the most important time in your life', was produced in a series of international shifts of medium and scale. It originated in his vivid declaration in conversation with a non-specialist at a workshop dinner, gained its canonical form in a colleague's monograph, and was amplified as a quotation on a poster derived from an undergraduate project. Although it drew on Wolpert's authority and he accepted his authorship, it thus represents a collective sifting of earlier claims for the significance of prenatal existence through the values of 1980s developmental biology. Juxtaposing a technical term with major life events has let teachers engage students, and researchers entice journalists, while sharing an in-joke that came to mark community identity. Serious applications include arguing for an extension of the fourteen-day limit on human-embryo research. On this evidence, quotations have been kept busy addressing every audience of specialized knowledge.
\end{abstract}

For an enterprise dedicated to innovation, science is surprisingly rich in quotations. When the influential developmental biologist, author and broadcaster Lewis Wolpert died in January 2021, colleagues and obituarists remembered his aphorism, 'It is not birth, marriage or death, but gastrulation which is truly the most important time in your life." ${ }^{1}$ This claim has been reproduced so often since 1983 that it may be 'the most famous quotation in embryology after William Harvey's "Ex ovo omnia" (Everything from an egg). ${ }^{2}$ Wolpert's assertion may or may not be true. Few competent judges would deny the momentousness of gastrulation, the set of processes early in animal embryogenesis which convert a mere ball of cells into a tiny three-layered body with primitive nervous system, muscles and gut arranged correctly in space; or that because so much happens, much can go wrong - but life is a continuum and one can hardly omit other stages at will. Put strict validity aside, however, and the statement has much to teach about the history of biology and the practice of quotation in science.

\footnotetext{
${ }^{1}$ Salah Elias (@theeliaslab), 'Every year my UG students are [astonished face emoji] when I introduce my lecture with "It is not birth ...." RIP Prof Lewis Wolpert [French flag]', 28 January 2021, 18:55, https://twitter.com/ theeliaslab/status/1354865701023055876, and other tweets; Georgina Ferry, 'Lewis Wolpert obituary', The Guardian, 29 January 2021, www.theguardian.com/science/2021/jan/29/lewis-wolpert-obituary; 'Professor Lewis Wolpert', Daily Telegraph, 30 January 2021, p. 27.

2 J.M.W. Slack, Egg \& Ego: An Almost True Story of Life in the Biology Lab, New York: Springer, 1999, p. 81.

(c) The Author(s), 2022. Published by Cambridge University Press. This is an Open Access article, distributed under the terms of the Creative Commons Attribution licence (https://creativecommons.org/licenses/by/4.0/), which permits unrestricted re-use, distribution, and reproduction in any medium, provided the original work is properly cited.
} 
While 'a necessity for historians', quotation has been painted as a 'luxury' for scientists. ${ }^{3}$ It is true that primary research articles in science have rarely employed direct, demarcated quotations, and analysis has focused on different forms of connection between texts, chiefly citation. ${ }^{4}$ Yet in other scientific contexts, as in medicine and society at large, self-conscious quoting has functioned generally to inspire, impress, amuse, console, emphasize, summarize, clarify, rebut, mock, admonish and especially to enlist support. ${ }^{5}$ Attributed quotations have also had specific uses in and around science. Quoting poetry has assimilated new, threatening or technical knowledge to a shared culture and heightened emotional responses to dry material. ${ }^{6}$ Scientists are such esteemed authorities that the name of Charles Darwin whose complicated published writings are rather unquotable - has been attached to 'six things' he 'never said'. press reports that make research news. ${ }^{8}$ Still, the utility of quotation is widely underestimated, especially for recent decades, in part because eloquence is not supposed to be either prized or possible in specialized science. ${ }^{9}$ I shall argue, by contrast, that established quotations have been gainfully employed not just in commentary on the aims and character of science and scientists, or in the occasional commemoration of discoveries and people, but also deep in disciplinary culture and all over its public manifestations.

This article tracks the construction of Wolpert's adage and its uses for communication in science. Showing how the maxim was made, as so often, in a series of changes of medium and scale will also explain how Wolpert was credited with a collaborative achievement. It all began with a move from a workshop conversation in Antwerp in 1979, where he launched the quip, to a British colleague's book, which added the reference to other life events; it continued with a shift from that book to a poster from an undergraduate project in Florida, which recognized the quotation as such. Pursuing this further will unravel a knotty web, including media that are too rarely considered together: symposium volumes, television programmes, textbooks, lectures, seminars, popularscience books, newspapers, press releases, tweets, the odd journal article and even a cabaret. ${ }^{10}$ It will become clear how the dictum, with its intriguing, provocative and amusing juxtaposition, proved effective in exposition and served as a badge of belonging to a research community. Taking seriously content as well as form will uncover how former claims for the importance of early life, including specifically fertilization and gastrulation, were refracted through the disciplinary commitments of developmental biology (as

\footnotetext{
${ }^{3}$ J.H. Hexter, 'The rhetoric of history', History and Theory (1967) 6, pp. 3-13, 7.

${ }^{4}$ Bruno Latour, Science in Action: How to Follow Scientists and Engineers through Society, Cambridge, MA: Harvard University Press, 1987, Chapter 1.

${ }^{5}$ Ruth Finnegan, Why Do We Quote? The Culture and History of Quotation, Cambridge: Open Book Publishers, 2011, pp. 74-5; Gary Saul Morson, The Words of Others: From Quotations to Culture, New Haven, CT: Yale University Press, 2011; a comedic classic: Robert K. Merton, On the Shoulders of Giants: A Shandean Postscript, New York: Free Press, 1965; most recently on medicine: Helen King, Hippocrates Now: The 'Father of Medicine' in the Internet Age, London: Bloomsbury Academic, 2020.

${ }^{6}$ Ralph O'Connor, The Earth on Show: Fossils and the Poetics of Popular Science, 1802-1856, Chicago: The University of Chicago Press, 2007; further: Leah Price, The Anthology and the Rise of the Novel: From Richardson to George Eliot, Cambridge: Cambridge University Press, 2000, Chapter 3.

7 'Six things Darwin never said - and one he did', Darwin Correspondence Project, www.darwinproject.ac.uk/ people/about-darwin/six-things-darwin-never-said (accessed 26 March 2021); James A. Secord, 'Global Darwin', in William Brown and Andrew C. Fabian (eds.), Darwin, Cambridge: Cambridge University Press, 2010, pp. 3157, 53-6; Janet Browne (ed.), The Quotable Darwin, Princeton, NJ: Princeton University Press, 2018, p. xv.

${ }^{8}$ Peter Conrad, 'Uses of expertise: sources, quotes, and voice in the reporting of genetics in the news', Public Understanding of Science (1999) 8, pp. 285-302.

${ }^{9}$ Steven Shapin, 'Words of wisdom', Nature (2005) 434, pp. 563-4.

${ }^{10}$ For the web: Bruce V. Lewenstein, 'From fax to facts: communication in the cold fusion saga', Social Studies of Science (1995) 25, pp. 403-36.
} 
distinct from human embryological anatomy) and how these changed. Having avoided earlier controversies, Wolpert's bon mot was recently adopted as part of scientists' push to extend the limit of fourteen days from fertilization after which cultured human embryos may no longer be used for research and must be destroyed. Its antecedents and assembly, authority and appeal exemplify practices that separate and exalt short, attributed texts. Its varied functions epitomize the substantial parts these quotations can play in public engagement, teaching and research.

\section{The most important moment}

Despite the confident tone, Wolpert's declaration is more open than many dicta; it does not demand assent to an explanation or approach, but points to a phenomenon. ${ }^{11}$ Several branches of knowledge have similarly been justified as telling us about crucial episodes in our shared past, from cosmology (above all the Big Bang) and geology (not least the Precambrian, with the origin of life) through evolutionary biology (the emergence, say, of eukaryotes and of humans) to archaeology and history (the New Stone Age and the Age of Revolutions). Genetics looks to ancestors. Other sciences, including embryology, have valorized the early lives of individuals. Some claims are contested. Most experts argue that, 'By the time a child reaches five years old, $90 \%$ of their brain has already developed', making 'the progression from birth to school ... the most important time of their lives', but critics of 'the myth of infant determinism' cite cases of recovery from adverse experiences. ${ }^{12}$ Individual embryos can exhibit remarkable plasticity, and closely related species may arrive at equivalent stages by different routes, but it has been self-evident to embryologists that fairly early events, if not always the very earliest, matter most. ${ }^{13}$

Before Wolpert, however, only general contentions counted as quotable. William Harvey's successors promoted eggs of various kinds, including against public ignorance, and those propagandizing for prenatal affairs trotted out a passage from the physician Sir Thomas Browne's Religio Medici (The Religion of a Physician) (1642):

and surely wee are all out of the computation of our age, and every man is some moneths elder than hee bethinkes him; for we live, move, have a being, and are subject to the actions of the elements, and the malice of diseases in that other world, the truest Microcosme, the wombe of our mother.

The Romantics rediscovered Browne's book, which has been incessantly reprinted, anthologized and quoted as a masterpiece of English prose, and Samuel Taylor Coleridge commented in an annotation, posthumously published in 1836, 'This is a most admirable passage. Yes, - the history of a man for the nine months preceding his birth, would, probably, be far more interesting, and contain events of greater moment than all the three score and ten years that follow it. ${ }^{14}$ By the 1940s, embryologists were using Browne

\footnotetext{
${ }^{11}$ Compare those disparaged in Gary Saul Morson, The Long and Short of It: From Aphorism to Novel, Stanford, CA: Stanford University Press, 2012, pp. 28-41.

${ }^{12}$ Elaine Hunter, 'How a child's brain develops from the womb to age five', Theirworld, 22 February 2017, https://theirworld.org/news/how-childs-brain-develops-from-womb-to-age-five; Jerome Kagan, Three Seductive Ideas, Cambridge, MA: Harvard University Press, 2000, Chapter 2.

${ }^{13}$ Occasional insistence that 'development is not merely an affair of early stages; it continues ... throughout life' confirms the success of this view: Julian S. Huxley and G.R. de Beer, The Elements of Experimental Embryology, London: Cambridge University Press, 1934, p. ix.

${ }^{14}$ Browne's Religio Medici and Digby's Observations, London: Clarendon Press, 1909, pp. 88-9; Samuel Taylor Coleridge, 'Notes on Sir Thomas Brown[e]'s Religio Medici, 1802', in The Literary Remains of Samuel Taylor Coleridge, ed. Henry Nelson Coleridge, vol. 1, London: Pickering, 1836, pp. 241-8, 244.
} 
and Coleridge to frame presentations for general readers or with some literary pretensions, but have had to share them with other aficionados of intrauterine life. ${ }^{15}$

Researchers on embryos had long made the point about prenatal existence in their own words. At least since the early nineteenth century, anatomists and physiologists wrote of the 'embryo (or the child in the womb)' that,

In its emergence and transformation, the creative force of nature reveals itself more clearly than anywhere, and the history of life in the womb is in this respect richer in content than that of all the rest of life, which in comparison to it is more uniform and only a development on the foundation previously formed. ${ }^{16}$

Embryologists told anyone who would listen that embryos are more interesting than the born, and none went further than the combative German Darwinist Ernst Haeckel.

Haeckel generated more-specific claims in trying to persuade larger audiences that everyone needed to know a science that medical students found hard. ${ }^{17}$ The phrase 'most important' litters his hectoring texts, which contain ancestors of Wolpert's statement for not one, but two stages. Having coined the term 'gastrula' in 1872, Haeckel insisted that it is 'the most important and most significant embryonic form of the animal kingdom'. 18 This 'stomach larva' developed by 'gastrulation', when cells on one side of the hollow blastula moved inside to make a two-layered body. Haeckel's theory that a gastrula-like animal, or gastraea, represented the common ancestor of all multicellular animals was contested, but in time embryologists accepted that birds and mammals gastrulate, too. Despite his best efforts, neither 'gastrula' nor 'gastrulation' became household words. $^{19}$

Haeckel nominated another process as the most important in individual development. In Die Welträthsel (The Riddles of the Universe) (1899), the anticlerical synthesis of philosophy and science that reached a global readership in two dozen languages, he settled on fertilization, first observed in sea urchins by a student of his a quarter-century before:

The most important moment in the life of every human being ... is the moment in which his individual existence begins ... in which the sexual cells of the two parents meet and coalesce for the formation of a single simple cell ... This ontogenic fact is supremely important ... In the first place, there follows from it the clear recognition that man, like all other complex animals [Gewebthiere], has received all personal

\footnotetext{
${ }^{15}$ Early embryological uses of Coleridge: Joseph Needham, Chemical Embryology, 3 vols., Cambridge: Cambridge University Press, 1931, vol. 1, p. 38; Jean Rostand, Adventures before Birth (tr. Joseph Needham), London: Gollancz, 1936, p. 7; Browne: George W. Corner, Ourselves Unborn: An Embryologist's Essay on Man, New Haven, CT: Yale University Press, 1944, p. 1; W.J. Hamilton, J.D. Boyd and H.W. Mossman, Human Embryology (Prenatal Development of Form and Function), Cambridge: Heffer \& Sons, 1945, p. i; R.J. Harrison, The Child Unborn, London: Routledge and Kegan Paul, 1951, p. v.

${ }^{16}$ Karl Friedrich Burdach, Der Mensch nach den verschiedenen Seiten seiner Natur: Anthropologie für das gebildete Publicum, Stuttgart: Balz, 1837, p. 487; also e.g. Samuel Christian Lucae, Grundriß der Entwickelungsgeschichte des menschlichen Körpers, Marburg: Krieger, 1819, p. 39. All translations are mine.

${ }^{17}$ Nick Hopwood, Haeckel's Embryos: Images, Evolution, and Fraud, Chicago: The University of Chicago Press, 2015, Chapters 3, 5, 7.

${ }^{18}$ Ernst Haeckel, 'Die Gastraea-Theorie, die phylogenetische Classification des Thierreichs und die Homologie der Keimblätter', Jenaische Zeitschrift für Naturwissenschaft (1874) 8, pp. 1-55, 16; L. Salvini-Plawen, 'Morphologie: Haeckels Gastraea-Theorie und ihre Folgen', in Erna Aescht, Gerhard Aubrecht, Erika Krauße and Franz Speta (eds.), Welträtsel und Lebenswunder: Ernst Haeckel-Werk, Wirkung und Folgen, Linz: Oberösterreichisches Landesmuseum, 1998, pp. 147-68.

${ }^{19}$ Unlike 'ecology', 'stem cell' (both Haeckel's) and 'dinosaur': Ralph O'Connor, 'Victorian saurians: the linguistic prehistory of the modern dinosaur', Journal of Victorian Culture (2012) 17, pp. 492-504.
} 
characteristics ... from his two parents through heredity; and, furthermore, the momentous conviction that the new person which thus arises cannot possibly claim to be 'immortal'.

'Person' may resonate with recent debates over fetal personhood, but Haeckel stressed heredity and the anti-religious implications.

By the early 1960s, when Lewis Wolpert, a South African émigré to London, completed his move from civil engineering to developmental biology, authors still nominated fertilization as the most important moment, and sometimes also gastrulation. ${ }^{21}$ The bestselling Jean Rostand had called the fertilization of the human egg 'the most important [phenomenon] in the universe, because it is by it that each of us begins'. As various investigators claimed to have seen human fertilization for the first time, its fascination endured. Some dubbed it 'zero hour', but more advanced accounts acknowledged that it is itself 'more crowded with important events' than any other period, and even that it is not such an obvious start. ${ }^{22}$ In a weighty synthesis, the textbook Principles of Embryology, Conrad Waddington hesitated to adopt 'the conventional point of origin', but could not deny 'that fertilisation is, normally at least, the most crucial event within the continuous series of changes by which the new creature comes into being'. ${ }^{23}$ Gastrulation nonetheless reigned supreme in an individual's taking shape, and elsewhere this senior figure justified discussing it at length, "because this is the most important process in the development of the embryo, and also as an example of how the same process appears in a slightly different form in different animals'. ${ }^{24}$ Waddington's gastrulation was more elaborate than Haeckel's; for experimental embryologists it involved at least the invagination of the mesoderm to fashion a three-layered embryo with the primitive parts organized in three dimensions from head to tail and back to front (Figure 1). ${ }^{25}$

Writers on pregnancy drew out a practical implication of the importance of early stages: women should be more aware that the germ develops in its essentials, and so particularly needs care, in the first four to six weeks; that is, before they may know they are pregnant. ${ }^{26}$ Obstetricians had traditionally been committed, by contrast, to the drama of birth and the first cry, to the tying and cutting of the umbilical cord as the 'instant' when

\footnotetext{
${ }^{20}$ Ernst Haeckel, Die Welträthsel: Gemeinverständliche Studien über monistische Philosophie, Bonn: Strauß, 1899, p. 73. All emphasis in quoted matter in this article is original.

${ }^{21}$ On Wolpert: James C. Smith, 'From engineering to positional information to public understanding: an interview with Lewis Wolpert', International Journal of Developmental Biology (2000) 44, pp. 85-91; Smith, 'Lewis Wolpert (1929-2021)', Development (2021) 148, dev199618; Lewis Wolpert, 'Perspective', Annual Review of Cell and Developmental Biology (2015) 31, pp. 1-9; Neil Vargesson, 'Positional information: a concept underpinning our understanding of developmental biology', Developmental Dynamics (2020) 249, pp. 298-312; Claudio D. Stern, 'Lewis Wolpert (1929-2021)', Developmental Cell (2021) 56, pp. 1218-20.

${ }^{22}$ Jean Rostand, L'aventure humaine: Du germe au nouveau-né, Paris: Fasquelle, 1933, p. 49 (still in print in the 1960s); more moderate ('about the most important in the universe for us') is Joseph Needham's translation, Rostand, op. cit. (15), p. 44; 'zero hour': Geraldine Lux Flanagan, The First Nine Months of Life, New York: Simon and Schuster, 1962, p. 26; 'crowded': Robert D. Allen, 'The moment of fertilization', Scientific American (July 1959) 201(1), pp. 124-34, 124. On claims to in vitro fertilization: Nick Hopwood, 'Artificial fertilization', in Nick Hopwood, Rebecca Flemming and Lauren Kassell (eds.), Reproduction: Antiquity to the Present Day, Cambridge: Cambridge University Press, 2018, pp. 581-96, 587-90.

${ }^{23}$ C.H. Waddington, Principles of Embryology, London: Allen \& Unwin, 1956, p. 45.

${ }^{24}$ C.H. Waddington, How Animals Develop, rev. edn, New York: Harper, 1962, p. 40.

${ }^{25}$ P. Collins and F.S. Billett, 'The terminology of early development: history, concepts, and current usage', Clinical Anatomy (1995) 8, pp. 418-25, 420-1.

${ }^{26}$ Ernst Kormann, Das Buch von der gesunden und kranken Frau in den ersten Stadien des ehelichen Lebens, Erlangen: Besold, 1877, p. 20; J.W. Ballantyne, Expectant Motherhood: Its Supervision and Hygiene, London: Cassell, 1914, pp. 234.
} 

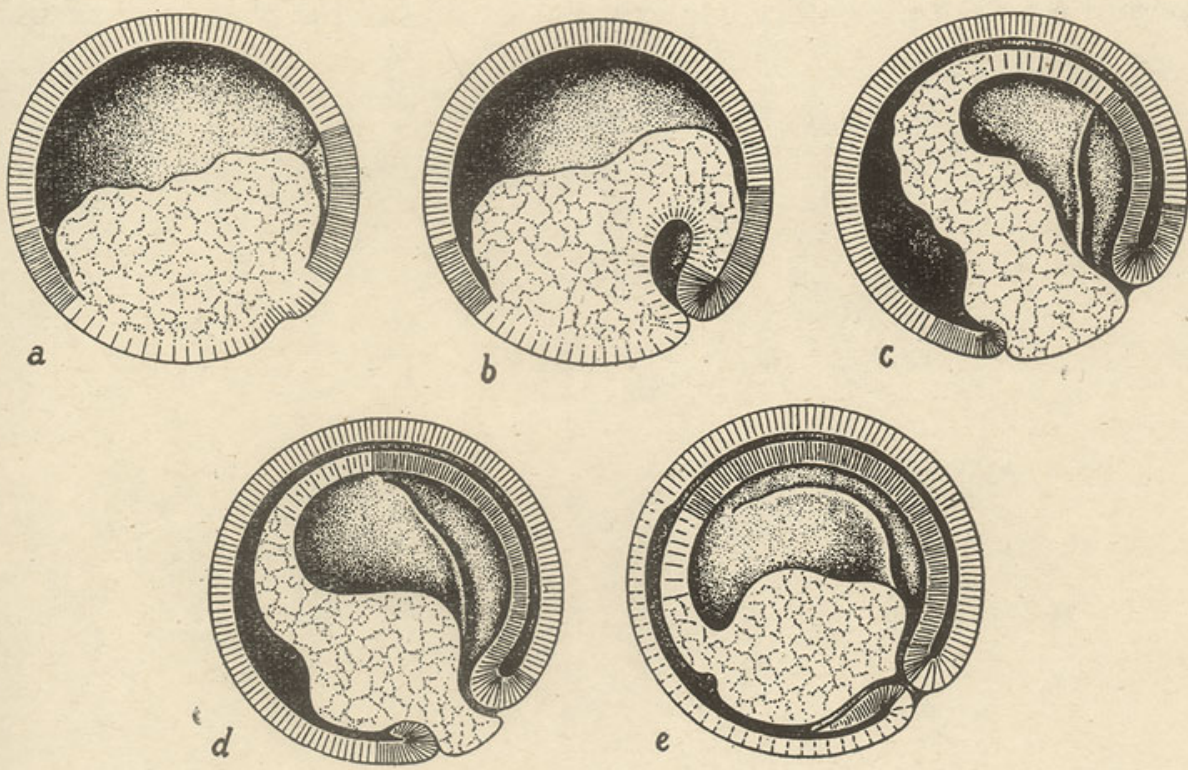

FIGURE 9.9

Semi-diagrammatic drawings of newt gastrulae sectioned through the dorso-ventral plane. The ridge on the wall of the archenteron in $c, d$ and $e$ shows where the endoderm and mesoderm are separating from one another.

(From Spemann 1938.)

Figure I. Canonical drawings of amphibian gastrulation from Hans Spemann's Embryonic Development and Induction (1938) in Conrad Waddington's textbook. They show the lower half of the blastula invaginating so that two germ layers, the (more densely shaded) mesoderm and the large, yolky cells of the endoderm, come to lie inside the third, the ectoderm. Drawings, which Spemann described as '[a]fter V. Hamburger and B. Mayer, unpublished', from C.H. Waddington, Principles of Embryology, London: Allen \& Unwin, 1956, p. 165.

'a biological parasite' becomes 'a separate individual'. ${ }^{27}$ Ever more of them nevertheless conceded the embryologists' point. In 1902, John Ballantyne of Edinburgh had doubted 'if any twelve hours after birth are just so full of possibilities, physiological and pathological, as is the time during which the fetus is passing through the maternal canals'. But, he continued, building on the recognition of antenatal life by nineteenth-century physiologists, psychologists and obstetricians,

it is certain that no period of nine months in childhood, in adult life, or in old age is so replete with occurrences, so diverse in kind, and of such far-reaching importance as is that spent by the unborn infant in utero. There is an intensity and a variety in the processes of antenatal life which have no equal at any other time. ${ }^{28}$

\footnotetext{
${ }^{27}$ Frederick C. Irving, foreword to Clement A. Smith, The Physiology of the Newborn Infant, Springfield, IL: Thomas, 1945, p. vii, but the author began by quoting Browne and promising 'some account of the embryonic and fetal origins' (pp. 3-4).

${ }^{28}$ J.W. Ballantyne, Manual of Antenatal Pathology and Hygiene: The Foetus, Edinburgh: Green \& Sons, 1902, p. 6; see also Ballantyne, op. cit. (26), p. 7: 'The building of a ship is more wonderful than the launching of it on its first cruise; the sculpturing of a statue is a greater thing than the unveiling of it; and so the making and growth of the
} 
Postwar obstetricians' construction of the fetus as a second patient intersected with arguments, in battles over abortion law reform, about when life begins, or whether it does, and about limits of viability. ${ }^{29}$ As several disciplines converged on prenatal activities, the anthropologist Ashley Montagu tirelessly quoted Coleridge as a prophet. ${ }^{30}$

Yet disciplinary differences matter, too. Founded in the 1950s as the main successor of an exhausted experimental embryology, developmental biology added genetics, cell biology, biochemistry and then also molecular biology. Presenting themselves as the true heirs to the embryological tradition, militant developmental biologists derided descriptive work on humans in anatomy departments and the phylogenetic speculations of comparative embryology, both research programmes in decline. As an academic subject that grew with the institutionalization of the life sciences, developmental biology was largely insulated from research on reproduction, let alone fetal politics. In principle, it tackled the whole living world; in practice, it focused increasingly on a handful of laboratory species, with mice as the model mammal. By the 1970s, the field was on the cusp of exciting innovation. ${ }^{31}$ Wolpert and his colleagues would channel prior claims for 'the most important moment' through its concerns.

\section{Specialists and dignitaries in conversation}

According to the only witness, Wolpert's statement began with the need to explain an esoteric topic to a non-specialist in conversation. Many quotable phrases arise in this way, because in speech greater pressure to perform meets fewer constraints than in print. $^{32}$ That has often left origins obscure, but in this case a rich archival record and some controlled guesswork allow reconstruction of a staged encounter between a civic and university milieu and international science.

From 30 May to 1 June 1979 Wolpert and his former post-doc Jonathan Slack attended a workshop on Mechanisms of Gastrulation organized by the chick embryologist Lucien Vakaet at the Rijksuniversitair Centrum Antwerpen (State University Centre AntwerpRUCA). During an economic crisis, Vakaet secured backing from several bodies and asked the governor of the Province of Antwerp, Andries Kinsbergen, to donate and preside

infant in the womb are more momentous than its entrance into the life that follows birth and its progress through the early months.' On Ballantyne: Salim Al-Gailani, 'Teratology and the clinic: monsters, obstetrics and the making of antenatal life in Edinburgh, c.1900', PhD dissertation, University of Cambridge, 2010; more generally: Caroline Arni, Pränatale Zeiten: Das Ungeborene und die Humanwissenschaften (1800-1950), Berlin: Schwabe, 2018; further: Sarah S. Richardson, The Maternal Imprint: The Contested Science of Maternal-Fetal Effects, Chicago: The University of Chicago Press, 2021.

${ }^{29}$ William Ray Arney, Power and the Profession of Obstetrics, Chicago: The University of Chicago Press, 1982; Monica J. Casper, The Making of the Unborn Patient: A Social Anatomy of Fetal Surgery, New Brunswick, NJ: Rutgers University Press, 1998; Martin H. Johnson and Nick Hopwood, 'Modern law and regulation', in Hopwood, Flemming and Kassell, op. cit. (22), pp. 597-611.

${ }^{30}$ E.g. Ashley Montagu, Life before Birth, New York: New American Library, 1964, p. 19.

${ }^{31}$ On the kinds of embryology: Nick Hopwood, 'Embryology', in Peter J. Bowler and John V. Pickstone (eds.), The Cambridge History of Science, vol. 6: The Modern Biological and Earth Sciences, New York: Cambridge University Press, 2009, pp. 285-315; Hopwood, 'Inclusion and exclusion in the history of developmental biology', Development (2019) 146, dev175448.

32 On simplification: Ludwik Fleck, Genesis and Development of a Scientific Fact (tr. Fred Bradley and Thaddeus J. Trenn, ed. Thaddeus J. Trenn and Robert K. Merton), Chicago: The University of Chicago Press, 1979, pp. 112-15; on conversation in earlier times: James A. Secord, 'How scientific conversation became shop talk', Transactions of the Royal Historical Society (2007) 17, pp. 129-56; for molecular biologist Jacques Monod's 'Anything that is true of $E$. coli must be true of elephants, only more so' as a rebuttal to a questioner after a lecture: Herbert C. Friedmann, 'From "butyribacterium” to "E. coli”: an essay on unity in biochemistry', Perspectives in Biology and Medicine (2004) 47, pp. 47-66, 59. 
over a banquet. Mentioning the external funding; the participation of 'very well-known professors, including from the USA and the United Kingdom'; and the 'very specific' field, Vakaet promised international resonance. The governor, a one-time professor of law at the RUCA who had led the confederation of this and two other institutions into one university, agreed to host the meal for some thirty people on the evening of 30 May at a restaurant run by the Provincial Institute for Food Companies. Vakaet asked the head of the RUCA, Marie de Groodt-Lasseel, who had underwritten the workshop, and other VIPs to join them. ${ }^{33}$ So, as Slack recalled, 'On the first evening, the speakers were invited to dinner with various local dignitaries'. ${ }^{34}$ Large conferences frequently held civic receptions; the intimacy of this one made interactions between specialists and locals more likely.

Presumably towards the end of the dinner, Governor Kinsbergen gave a speech in English based on information from Vakaet. 'Gastrulation is a very important period in the development of a germ', the well-briefed lawyer explained. 'During this period it develops from a shapeless mass of cells into a being in which the future adult form can be recognized. This change of form is brought forth by the coordinated behaviour of its cells.' Having taken Vakaet's bait, he argued that the questions raised were not 'purely academic', for the answers 'might be of utmost practical value' in tackling ageing and cancer and thus in promoting 'good health' and 'happiness'. ${ }^{35}$

At least one dignitary would have benefited from the governor's description earlier in the evening, and for some foreign scientists the 'excellent dinner in this marvellous place' was hard work. ${ }^{36}$ According to Slack,

Lewis and I found ourselves sitting at a table with a Belgian paediatrician. The organisers had evidently felt that scientists who deal with embryos would have something in common with a doctor who dealt with children, but actually we found the common ground distinctly limited. 'What is the meeting about?' the Belgian doctor asked. 'It's about gastrulation', we said. 'Gastrulation, what is that?' said the doctor. 'It's the most important time of your life', said Lewis, without a moment's hesitation. $^{37}$

Let us consider Wolpert and the paediatrician in turn.

Vakaet had initially asked Wolpert to talk about his lab's current research on the chick limb in relation to positional information. That is Wolpert's influential idea that cells are told their place in a coordinate system and interpret this position by differentiating in ways that produce spatial patterns independent of size; his analogy was of the blue, white and red stripes on a French flag. This talk was scheduled for the somewhat separate third day, sponsored by the Belgian Society for Cell Biology, on 'Early embryological systems that may be used as models by cell biologists'. Also relevant was Wolpert's

\footnotetext{
${ }^{33}$ Vakaet to Kinsbergen, 9 March 1979, Rijksarchief te Antwerpen 881.1164, Redevoeringen Gouverneurs, 1911-1993, 'Diner aangeboden aan de deelnemers van het congres "Mechanisms of Gastrulation" PIVA (A. Kinsbergen) (30/05/1979)' (hereafter RA); J. Coveliers to Vakaet, 23 April, and Vakaet to de Groodt-Lasseel, 8 May 1979, Archive of the Belgian Society for Cell and Developmental Biology, ring binder on International Symposium on Mechanisms of Gastrulation (hereafter MG), tabblad Organisatie Fin 2. On Vakaet: Paulette van Gansen, 'Lucien Vakaet, an avian embryologist', International Journal of Developmental Biology (1992) 36, pp. 43-5; on the university: Piet Lenders, Ontstaan en groei van de Universiteit van Antwerpen, Leuven: Garant, 1991.

${ }^{34}$ slack, op. cit. (2), pp. 80-1.

35 'Rede uitgesproken door Gouverneur A. Kinsbergen ...', 30 May 1979, RA.

${ }^{36}$ Quotation: Vakaet, [speech at dinner, 30 May 1979], MG, tabblad Organisatie Fin 2.

${ }^{37}$ Slack, op. cit. (2), p. 81. Wolpert's first published comment is consistent with his having accepted this story in full: Lewis Wolpert, The Triumph of the Embryo, Oxford: Oxford University Press, 1991, p. 12.
} 
collaboration in the early 1960s with the Swede Trygve Gustafson in work on gastrulation in sea urchins, a traditional organism for experimental embryology. When Gustafson appeared reluctant to attend, Vakaet persuaded Wolpert also to screen and comment on their film. This had made an 'overwhelming impression' on Vakaet, a fan of films in a field that used them to explore how cells move. ${ }^{38}$

Wolpert was professor of biology as applied to medicine at the Middlesex Hospital Medical School, a role that had perhaps sensitized him to medical ignorance. He had never researched humans, but was happy to extrapolate from urchins and chicks. He had done a little broadcasting and would do more. With his left-wing background, lifelong atheism, interest in communicating science to the general public and rather positive view of the gastraea theory, he can be expected to have read Haeckel as well as Waddington. ${ }^{39}$ But his sentence was pithier than theirs and the second person ('your life') made it more personal, too. A willing performer, known for spontaneous brilliance, he must have been asked the question before.

Slack remembers the paediatrician as 'maybe in his forties', probably Flemish and Antwerp-based. ${ }^{40}$ Although a bit older (fifty-five), the obvious invitee is the professor of paediatrics Robert Clara, the newly elected head of another part of the university, the Universitaire Instelling Antwerpen (University Institution Antwerp). Clara might have preferred a seat at a top table, but could have seemed a suitable interlocutor for someone of Wolpert's distinction. He had published on metabolic, muscle and infectious diseases of children, was beginning investigations of lead poisoning and of child abuse, and had broad interests in medicine. ${ }^{41}$ Still, 'it was hard to find things to talk about'. ${ }^{42}$

Clara had studied medicine in Ghent thirty years before, but few medics liked embryology, which he had not needed in his research career. We might also suspect no burning curiosity about paediatrics on the other side. The paediatrician was not necessarily ignorant, however. Conceivably - this is a stretch, but an instructive one - his frank question rather reveals a difference between developmental biology and medical embryology which could have led a diligent, up-to-date student to miss out. Textbooks of human embryology, in the 1970s as in the 1940s, discussed the formation of a trilaminar embryo in week 3, but fought shy of the terms 'gastrula' and 'gastrulation'. So little was known about humans that even the most advanced text used the word in only the comparative contexts that human embryologists, their very field founded in opposition to Haeckel, tended to avoid. ${ }^{43}$ Medical textbooks also highlighted the 'critical period' of teratogen sensitivity for 'major congenital malformations', which pushed 'undoubtedly the most important period' into the fourth to eighth weeks. ${ }^{44}$

\footnotetext{
${ }^{38}$ Vakaet to Wolpert, 14 November 1978, 2 (quotation), and 30 January 1979, MG, tabblad L. Wolpert; Jesse Olszynko-Gryn, 'Filming fly eggs: time-lapse cinematography as an intermedial practice', Isis (2021) 112, pp. 307-14.

${ }^{39}$ On the gastraea: Wolpert, op. cit. (37), p. 196.

${ }^{40}$ Slack to the author, 10 February, 19 April 2021.

${ }^{41}$ On Clara: 'Curriculum vitae met aanvullingen 1979-1983', Universiteitsarchief Antwerpen, 15378; Kris Merckx, Dokter van het volk, Berchem: EPO, 2008, pp. 256-69.

${ }^{42}$ Slack to the author, 10 February 2021.

${ }^{43}$ W.J. Hamilton and H.W. Mossman, Hamilton, Boyd and Mossman's Human Embryology: Prenatal Development of Form and Function, 4th edn, Cambridge: Heffer \& Sons, 1972; see also Keith L. Moore, The Developing Human: Clinically Oriented Embryology, 2nd edn, Philadelphia: Saunders, 1977; and Jan Langman, Medical Embryology, 4th edn, Baltimore: Williams \& Wilkins, 1981. Langman had been translated into Dutch and French. On the making of human embryology: Nick Hopwood, 'Producing development: the anatomy of human embryos and the norms of Wilhelm His', Bulletin of the History of Medicine (2000) 74, pp. 29-79.

${ }^{44}$ Moore, op. cit. (43), p. 59, but see also 136; further: Heather A. Dron, 'Teratology transformed: uncertainty, knowledge, and conflict over environmental etiologies of birth defects in midcentury America', PhD dissertation, History of Health Sciences, University of California, San Francisco, 2016.
} 
Wolpert surely explained gastrulation, and the matter might have ended there. Vakaet told the governor, 'The dinner ... gave this Symposium a splendour which, as they repeatedly assured me, left an overwhelming impression on our foreign guests. ${ }^{45}$ The languishing conversation at one table testifies to the difficulty of exchange between biomedical disciplines, but such occasions also foster the invention of striking expressions, and Wolpert's Boswell would give his quite an afterlife.

\section{Embellished in print}

In making a quotation, the process of recording a phrase for posterity can be as creative as it is crucial. Slack provides a plausible account of how he transposed the riposte from conversation to print and another project of communication across fields, and how he gave Wolpert's quip its definitive form.

slack had done a PhD in molecular biology, but Waddington's Principles and a lecture by Wolpert inspired him to work with Wolpert and become a respected amphibian embryologist. $^{46}$ In 1983, four years after the Antwerp meeting, his book From Egg to Embryo introduced embryology to molecular biologists, who were keen to tackle development more aggressively, and focused attention on the making of the body plan. Chapter 1 begins,

This book is about how an egg becomes an animal. Attention will be concentrated on early development because this is the time at which the important events are happening. As everyone knows the human gestation period is about 9 months long, but it is not so commonly appreciated that the basic body plan of the embryo becomes established during the very short period from 1 to 4 weeks after fertilisation. During this time an apparently homogeneous group of cells, the inner cell mass of the blastocyst, becomes transformed into a miniature animal consisting of central nervous system, notochord, lateral mesoderm, somites, branchial arches, integument and gut. All of these parts contain specific types of cell and all lie in the correct positions relative to one another.

Having acknowledged later growth and differentiation, and the advent of peculiarly human characteristics, Slack insisted that 'all this takes place on the framework of the basic body plan which was laid down in early development'. Then, to make the opening 'compelling' for those not scared off by the anatomical terms - he added to the end of that first paragraph a contrast that intensified Wolpert's claim: 'As Wolpert has emphasised, it is not birth, marriage or death, but gastrulation which is truly the most important time in your life. ${ }^{47}$

A more specialized book in the same Cambridge series, which targeted 'advanced undergraduates and graduate students', off-puttingly opened a chapter by warning readers that gastrulation is 'very complex' and that 'no adequate general definition has ever been given'. ${ }^{48}$ Bidding for a somewhat wider audience, Slack invited in 'all students, teachers and research workers who are interested in embryos'. 'I thought "birth, marriage and death" would sound good, as the recognised landmarks of life to lay people. ${ }^{49}$ As matters

\footnotetext{
${ }^{45}$ Vakaet to Kinsbergen, 14 June 1979, RA.

${ }^{46}$ Slack, op. cit. (2), pp. 19-21.

47 J.M.W. Slack, From Egg to Embryo: Determinative Events in Early Development, Cambridge: Cambridge University Press, 1983, p. 3; 'compelling': Slack to the author, 2 February 2021.

${ }^{48}$ Pieter D. Nieuwkoop, A.G. Johnen and B. Albers, The Epigenetic Nature of Early Chordate Development: Inductive Interaction and Competence, Cambridge: Cambridge University Press, 1985, back jacket, p. 125, with reference to William W. Ballard, 'Problems of gastrulation: real and verbal', BioScience (1976) 26, pp. 36-9.

${ }^{49}$ Slack, op. cit. (47), p. ix; Slack to the author, 2 February 2021. Developmental biologist N.J. Berrill had tried a similar ploy in The Person in the Womb, New York: Dodd, Mead, 1968, p. 51, but it did not resonate: 'The time when
} 
of civil registration as much as parish records, these were not just for the religious. It seems less relevant that prenatal diagnosis was reducing the significance of birth as a threshold, that marriages were more easily ended after the Divorce Reform Act 1969 but not yet open to people of the same sex, or that Christianity was losing its role in attitudes towards death.

The claim is disciplinarily specific. Slack's initial paragraph said more about humans directly than did the rest of his book, but a human embryologist would not have written it. With biologists only starting to use in vitro fertilization (IVF) to study human development before implantation (attachment to the wall of the uterus), anatomists still dominated human embryology as a rather separate field. Their setter of standards, Ronan O'Rahilly of the Carnegie Laboratories of Embryology, would put 'gastrulation' in a table of 'discarded and replaced terms' as 'alternative, inappropriate, or incorrect', and 'not used' ${ }^{50}$ The Wolpert-Slack statement, as it will probably never be recognized, comes out of the opening up of developmental biology to molecular biologists seeking to solve the problem of body plan formation using model organisms.

\section{A poster brings fame}

Slack had not quite quoted, because he embellished and because he neither gave a source nor used quotation marks. But as his book circulated internationally, readers repackaged the sentence, principally onto a poster, so that it eclipsed older versions of the claim. They made a quotation by copying the last nineteen words plus the attribution.

From Egg to Embryo was widely noticed - the molecular biologist Gunther Stent echoed the gastrulation passage in two reviews, one in the hot journal Cell-and much read. ${ }^{51}$ Weekly readings were held in Walter Gehring's Basel lab, which had recently co-discovered the homeobox, a DNA sequence shared among genes involved in specifying the anteroposterior axis in a then-astonishing variety of animals. ${ }^{52}$ Unusually for a moderately specialized series, the title went into paperback within a year, and sold about three thousand copies, then four thousand in a second edition. The accumulation of molecular data changed much, but the first paragraph stayed. ${ }^{53}$

Slack learned in (probably early) 1984 that the phrase had broken through: 'Lewis phoned me and said "You have made me famous!" ${ }^{54}$ Wolpert had received some posters from a fellow urchin enthusiast, John Morrill of New College of the University of South Florida in Sarasota. Morrill produced these out of the undergraduate research that this gruff and demanding but charismatic and generous professor of biology fostered at a peripheral institution, imbued with the progressive vibe of the 1960s, from which he inspired

you and I were seventeen may have been critical in our adolescent romantic life, but when we were three or four weeks old, reckoning from conception, we were in a much more crucial stage. For we were more fishlike when we were a quarter-inch long than we have been at any time since. And to students of human development this is undoubtedly the most fascinating stage of all.'

${ }^{50}$ Ronan O'Rahilly and Fabiola Müller, Developmental Stages in Human Embryos, Including a Revision of Streeter's 'Horizons' and a Survey of the Carnegie Collection, Washington, DC: Carnegie Institution of Washington, 1987, p. 7; also O’Rahilly, 'Human embryo', Nature (1987) 329, p. 385; Hopwood, op. cit. (22).

${ }^{51}$ The reviews: Gunther S. Stent, 'From probability to molecular biology', Cell (March 1984) 36(3), pp. 567-71; Stent, Trends in NeuroSciences (April 1984) 7(4), pp. 133-4.

52 Slack to the author, 2 February 2021; Walter J. Gehring, Master Control Genes in Development and Evolution: The Homeobox Story, New Haven, CT: Yale University Press, 1998.

${ }^{53}$ J.M.W. Slack, From Egg to Embryo: Regional Specification in Early Development, 2nd edn, Cambridge: Cambridge University Press, 1991, p. 1; Jim Smith, 'Developing concepts', Trends in Cell Biology (1991) 1, p. 176; print runs: Slack to the author, 4 February 2021.

${ }^{54}$ Slack to the author, 2 February, 19 April 2021. 
many students to go on in science. ${ }^{55}$ For their senior projects several undergraduates used a scanning electron microscope (SEM), which the Natural Sciences Division had acquired in the early 1980s, to make stunningly three-dimensional images. ${ }^{56}$ Laurinda Santos had transferred from another seaside campus, the University of Connecticut at Groton, 'enticed by the high teacher student ratio and culture of motivated students and independent study'. She found the atmosphere 'relaxed and friendly' and '[1]oved exploring ideas and concepts with Dr. Morrill', as well as the 'ease and beauty' of collecting urchins and the 'fascination of being able to see individual cells and their connections and presumed movement'. ${ }^{57}$

Santos's thesis compared morphogenesis, or the generation of shape, in normal embryos of the green sea urchin from early cleavage through late gastrulation with that in those treated with lithium, which causes the tissues to 'exogastrulate'; that is, move out instead of in. Her introduction ended by highlighting gastrulation as 'a period of development rich in cell-cell interactions, extracellular materials, innate cell behavior, and changing cell morphologies. As such it is an excellent model for developmental biology. Furthermore, "It is not birth, marriage, or death ...". The quotation gave the work significance, as it would in many later theses, but her project aimed not just to write a dissertation: the task was above all to produce a poster, a display of captioned pictures to discuss informally in a 'poster session' at a conference. This alternative to a talk in a 'platform session' was then new enough that Santos included an appendix, 'Basic guidelines for a successful poster'. She made hers for the Southeastern Conference on Developmental Biology, a regional event of the Society for Developmental Biology (SDB) (Figure 2). Normal and lithium-treated mid-gastrulae have pride of place in the centre as photomontages, which offer higher quality than single shots and so can be blown up, but the quotation did not appear. ${ }^{58}$

Perhaps because the 'eerie beauty of the SEM images speaks to a link between the seemingly disparate worlds of art and science', Morrill reckoned it would be cool to make a different kind of poster, less didactic than an entry for a poster session or a wall chart: an arresting image with an inspirational statement. ${ }^{59}$ He asked a nearby

\footnotetext{
${ }^{55}$ Jon Cohen, 'Scientists who fund themselves', Science (1998) 279, pp. 178-81; Jacqueline S. McLaughlin, 'In tribute to my mentors', American Biology Teacher (2009) 71, pp. 134, 136; 'Remembering John B. Morrill, Emeritus Professor of Biology (1929-2010)', New College News (New College of Florida), 12 August 2010, www. ncf.edu/news/news/remembering-john-b-morrill-emeritus-professor-of-biology-1929-2010; Joshua Waxman, Mark Q. Martindale and Gary M. Wessel, 'John Morrill: scientist, educator, friend (Nov. 20, 1929-Aug. 9, 2010)', Molecular Reproduction and Development (2010) 77(10), pp. i-iii; Randall T. Moon, 'Remembering John B. Morrill', Developmental Biology (2010) 348, p. 2.

56 'A new approach to inner space', New College Nimbus (December 1984) 1(1), p. 2.

57 Santos to the author, 17 April 2021.

${ }^{58}$ Laurinda L. Santos, 'Morphogenesis from early cleavage through gastrulation in normal and lithium-treated sea urchin embryos: an SEM study', senior project, Division of Natural Sciences, New College of the University of South Florida, 18 May 1984, pp. 9 (quotation), 109-13 (guidelines), 116 (conference); on this sort of poster: Françoise Waquet, 'Lire debout: Le poster comme pratique de lecture dans le monde scientifique', TECA (2012) 2(1), pp. 9-22; on photomontages: John B. Morrill, 'Scanning electron microscopy of embryos', in Thomas E. Schroeder (ed.), Methods in Cell Biology, vol. 27: Echinoderm Gametes and Embryos, New York: Academic Press, 1986, pp. 263-93, 288-9.

59 'A new approach', op. cit. (56), which mentions Morrill's producing a poster composed of images from Santos's project. Today a physician, she had been unaware of the success of the other poster: Santos to the author, 30 March, 17 April 2021. On posters: Elizabeth E. Guffey, Posters: A Global History, London: Reaktion Books, 2015; in public health, most recently: Hannah J. Elizabeth, Gareth Millward and Alex Mold, “'Injections-while-you-dance": press advertisement and poster promotion of the polio vaccine to British publics, 1956-1962', Cultural and Social History (2019) 16, pp. 315-36; on wall charts: Massimiano Bucchi, 'Images of science in the classroom: wallcharts and science education, 1850-1920', BJHS (1998) 31, pp. 161-84.
} 


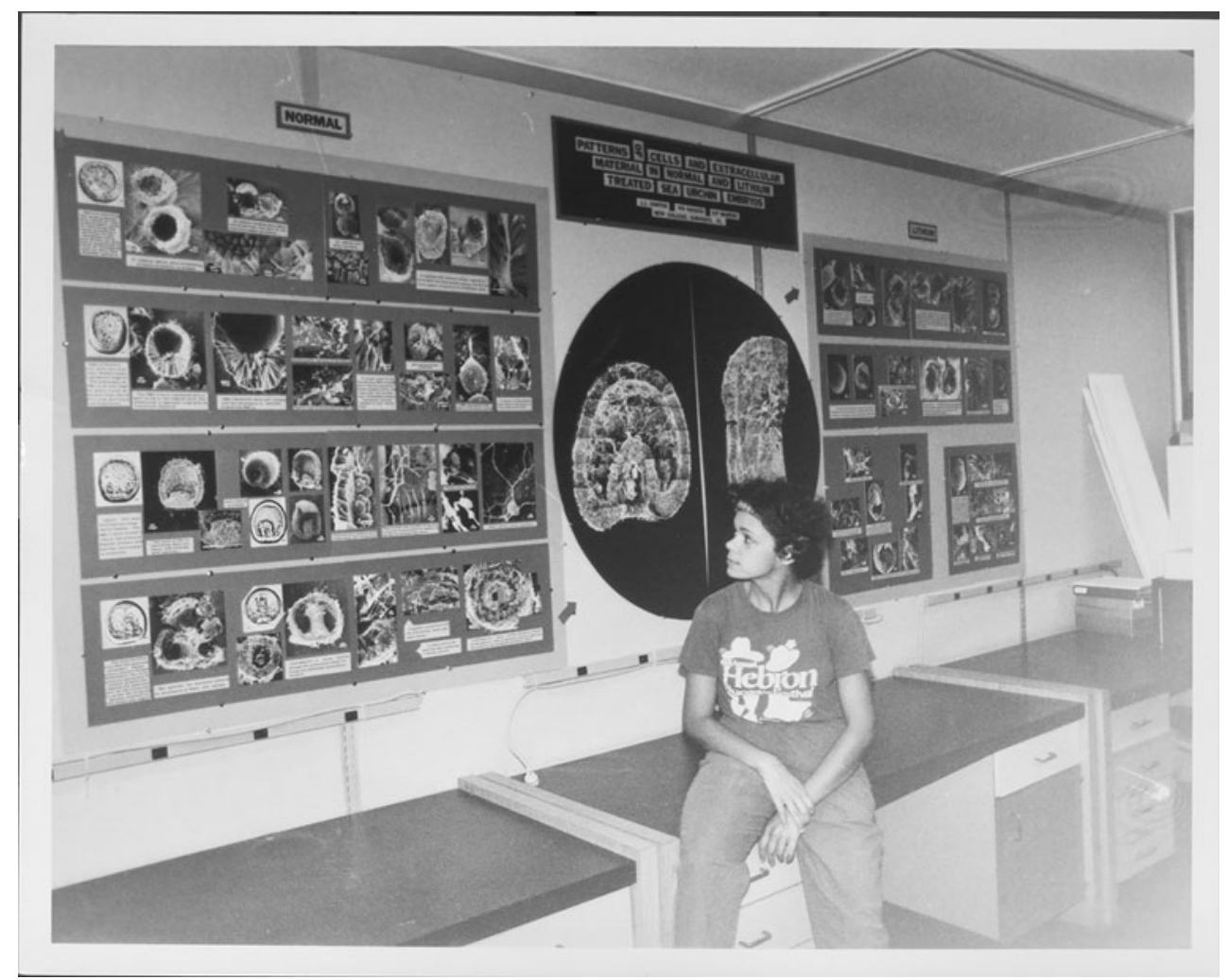

Figure 2. Laurinda Santos, wearing a T-shirt for a 1981 Connecticut bluegrass festival, photographed at New College in April 1984 in front of her four-by-ten-foot poster, co-authored with Deni Galileo and Shawn Murphy. With normal embryos left and lithium-treated right, in the left middle is the montage of some thirty-five prints of a fixed, freeze-dried and fractured mid-gastrula (twelve hours after fertilization) taken with an ISI SS-40 SEM at a beam voltage of $10 \mathrm{kV}$ and 5,000x magnification. Photo by F[urman] C. A[rthur] from Digital Repository, Jane Bancroft Cook Library, New College of Florida, http://ncf.sobek.ufl.edu/AA00027050/0000I.

printer to reproduce the normal montage with Wolpert's claim for his own favourite topic (Figure 3). That an urchin gastrula became developmental biologists' poster embryo, and that an invertebrate illustrates a sentence about humans, testifies to their confidence in model organisms. Crediting Wolpert might have seemed appropriate also because he had collaborated not just on the standard work on urchin gastrulation, but also on the application to them of transmission electron microscopy.

Morrill likely brought his posters to the symposium on the Cellular and Molecular Biology of Invertebrate Development at the Belle W. Baruch Field Laboratory on the estuary in Georgetown, SC on 25-7 April 1984, for which Santos made hers and at which Morrill talked about their work. This unusual conference was dedicated to the memory of the local African American biologist Ernest Everett Just, of whom a biography by the MIT historian of science Kenneth Manning had been enjoying great success. Manning was in South Carolina to speak in the public schools at the invitation of George Fulton of the state Commission on Higher Education, which hoped to make Just 'a model for minority students with an interest in the sciences'. Fulton arranged for Manning to address the Baruch meeting and for several African American scientists from the historically black South Carolina State College to attend as special guests. 


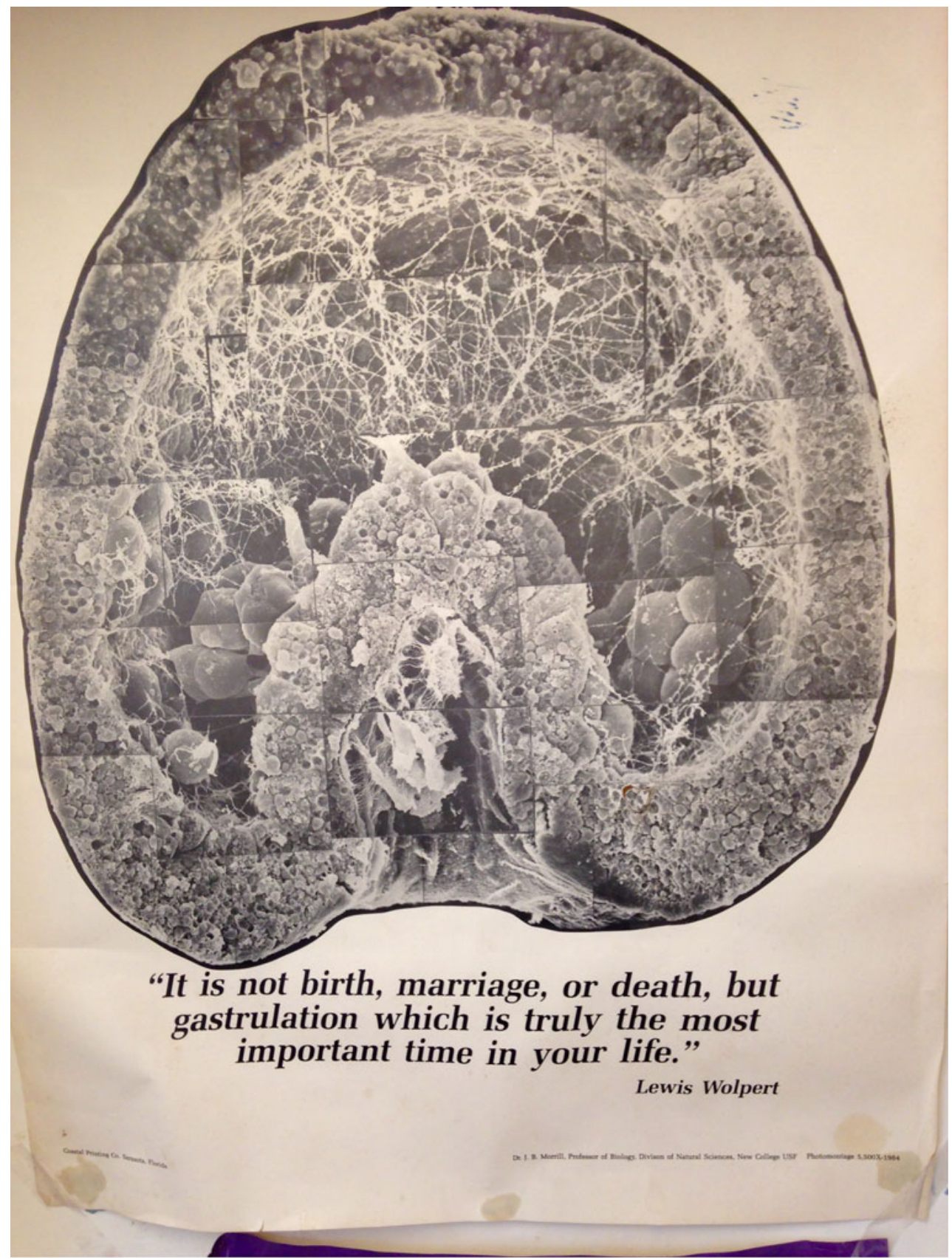

Figure 3. John Morrill's sea urchin gastrula poster, showing its age and Blu Tack marks, on the kitchen door of Lewis Wolpert's garden flat in north London in 2015. The redundant bold italics and the spacing, between image and text and between the words, look home-made. Printed by Coastal Printing of Sarasota in Melior; photo by Wolpert with thanks to Jim Smith. 
Here, in an atmosphere of 'racial harmony', we can imagine people viewing Santos's poster on the afternoon reserved for the session, and encountering Morrill's for the first time. ${ }^{60}$

Morrill's poster powerfully combined quotation and image. Santos's project had one in the thesis and the other on her poster (slides of which accompanied the text). In the symposium volume published the following year, the statement Slack credited to Wolpert is the epigraph to the first chapter, by Morrill and Santos, and a figure includes the montage as one panel of six, with labels and a scale bar. ${ }^{61}$ Morrill's poster brought image and quotation strongly together and took them into the everyday life of developmental biology in ways no publication could. William Jeffery, who carried a poster home from Georgetown or another conference and put it up in his lab at the University of Texas at Austin, found it 'eye-opening' because 'it showed the fibrous interior of the blastocoel', which he 'had considered ... merely a liquid filled space'. ${ }^{62}$ Morrill sent former students posters and they passed these on to their own students and post-docs. ${ }^{63}$ "He would show up to meetings with a handful - pass 'em out and accept a beer or a handshake in return', or 'place them on a table and they would always be snatched up very quickly'. ${ }^{64}$ Blu Tacked to a wall, or 'hanging above a ... microscope', display and viewing were more collective than of any book and more routine and long-lasting than of any film (Figure 4). ${ }^{65}$ Lab members saw the posters daily and group leaders passed them on to their successors. ${ }^{66}$

Television programmes, conference proceedings and textbooks repeated the sentence, which also went into other languages, but Morrill's poster was the main early vector among researchers (more potent than Slack's book or the reviews), and seems to have been unique in developmental biology for a time. ${ }^{67}$ In 1987, the Company of Biologists'

\footnotetext{
${ }^{60}$ Roger H. Sawyer and Richard M. Showman (eds.), The Cellular and Molecular Biology of Invertebrate Development, Columbia: University of South Carolina Press, 1985, pp. v, X-xii, 1-2; information and first quotation from copy of National Science Foundation proposal (which does not list Morrill as an invited speaker) attached to Sawyer to Anne 'Holly' Schauer, 15 November 1983, SDB Records (collection 22), Center for Biological Sciences Archives, Special Collections, University of Maryland, Baltimore County, Box 29, Folder 13; Kenneth R. Manning, Black Apollo of Science: The Life of Ernest Everett Just, New York: Oxford University Press, 1983; further information and second quotation from Zoom interview with Manning, 20 May 2021. NSF award abstract \#8404213, www. nsf.gov/awardsearch/showAward?AWD_ID=8404213 (accessed 19 July 2021), gives the dates 26-8 April. Unsurprisingly, no attendee I asked could reliably recall posters.

${ }^{61}$ John B. Morrill and Laurinda L. Santos, 'A scanning electron microscopical overview of cellular and extracellular patterns during blastulation and gastrulation in the sea urchin, Lytechinus variegatus', in Sawyer and Showman, op. cit. (60), pp. 3-33, 3, 22. A quotation from Just opened the 'Materials and methods' (p. 4).

${ }^{62}$ William Jeffery to the author, 28 February 2021.

${ }^{63}$ Randall Moon to the author, 12 February 2021; Deborah Hursh to the author, 13 February 2021.

${ }^{64}$ Wessel in Waxman, Martindale and Wessel, op. cit. (55), p. iii; Joshua Waxman to the author, 15 February 2021.

${ }^{65}$ Quotation: Pamela J. Johnson, 'Hire purpose: Scott Fraser', USC Dornsife, 7 May 2013, https://dornsife.usc. edu/news/stories/1382/hire-purpose-scott-fraser; Slack's hung in his office: Slack to the author, 4 February 2021.

${ }^{66}$ Katerina Ragkousi (@RagkousiK), 'Its an honor and a duty ...', 2 July 2019, 00:11, https://twitter.com/ RagkousiK/status/1145832235049709569; Nicole Theodosiou (@theodosn), ‘I received the same poster ...', 3 July 2019, 00:12, https://twitter.com/theodosn/status/1146194857540689920. Having some reservations about the quotation, Ragkousi has used it 'to remind students that indeed gastrulation is important but other processes are as essential': Ragkousi to the author, 1 March 2021.

67 'Genesis', Horizon, BBC, first broadcast 13 January 1986, and as 'How babies get made', NOVA, WGBH, first widely broadcast 13 January 1987; Scott F. Gilbert, Developmental Biology, 2nd edn, Sunderland, MA: Sinauer, 1988 , p. 112, which also put three sea urchin gastrulae, including Santos and Morrill's montage, on the title page and part openers; an early translation: François Jacob, 'L'embryologie devenue moléculaire', Médecine/ Sciences (1989) 5(1), pp. 6-7. Some referenced the poster: David L. Stocum, 'Dynamics of the gastrulation movements and determination of the mesoderm in amphibian embryos', in Edward F. Rossomando and Stephen
} 

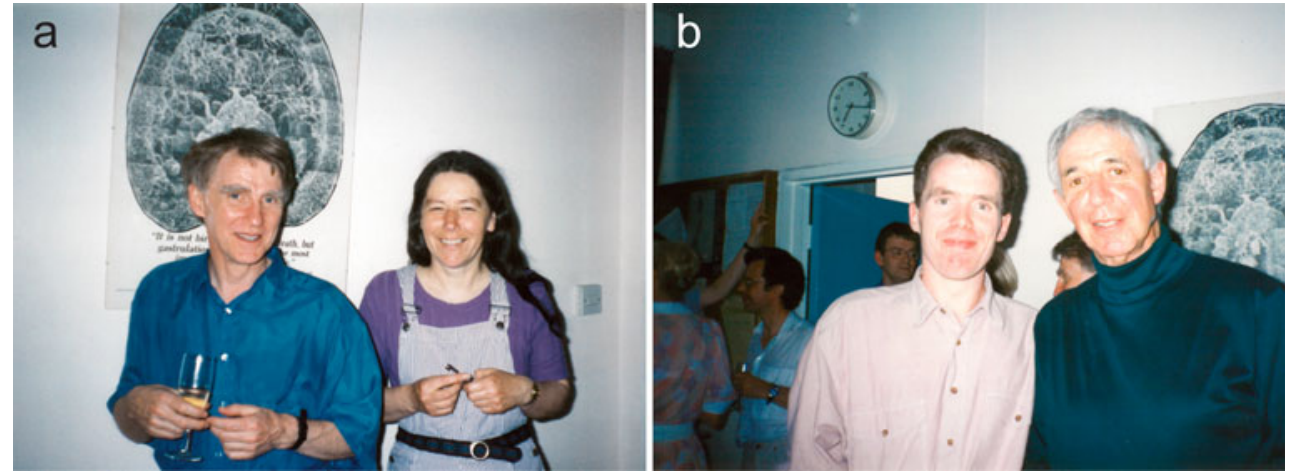

Figure 4. Morrill's poster in the Wolpert lab seminar room in the Windeyer Building at the Middlesex Hospital during a leaving party in June 1996. (a) Dennis Summerbell and Cheryll Tickle; (b) Neil Vargesson and Wolpert, with Jonathan Slack (in white shirt) and Michael Richardson in the background. Photos courtesy of Neil Vargesson from his 'Positional information: a concept underpinning our understanding of developmental biology', Developmental Dynamics (2020) 249, pp. 298-312, 305, (c) 2019 Wiley Periodicals, Inc.

Journal of Embryology and Experimental Morphology advertised its relaunch as Development with colour posters, and other journals eventually followed suit. ${ }^{68}$ Morrill's was a more direct model for a poster of a chick embryo that the SDB produced in 2001 or 2002 as a memorial to Viktor Hamburger, the legend from Hans Spemann's celebrated laboratory who set up the chick normal stages. This showcased a saying from Hamburger, which appears also to have begun in speech and been committed to print by a colleague: 'Our real teacher always has been and still is the embryo - who is incidentally the only teacher who is always right'. ${ }^{69}$ Being credited with a quotation on a successful poster, while still alive, was one of Wolpert's more unusual routes to fame.

\section{'I have been quoted as saying ...'}

After 'an explosion in the number of publications concerned with gastrulation', Claudio Stern and Phil Ingham quoted 'Lewis Wolpert's famous statement' in the preface to a 1992 symposium volume. ${ }^{70}$ The dictum borrowed and boosted Wolpert's renown, but he had a complex relationship with the words of which Slack's generosity had made him the author.

Wolpert was a dominant figure in UK developmental biology. In the 1990s, his actions as a science warrior earned him loathing from sociologists of science, but within his field he was held in affection and known for welcoming the young. Yet he was a theoretician, and his dislike of benchwork could have conflicted with the community value of direct engagement with beautiful embryos. The Hamburger quotation reflects that, as does the homily, also excerpted, in which the house historian of US developmental biology

Alexander (eds.), Morphogenesis: An Analysis of the Development of Biological Form, New York: Dekker, 1992, pp. 31986, 376.

${ }^{68}$ Developmental Dynamics gave away posters of normal stages from around 2000: Gary Schoenwolf to the author, 4 September 2006; see also Posters, Audio-visual Section, The Node, https://thenode.biologists.com/ audio-visual-section/\#Posters (accessed 25 June 2021).

${ }^{69}$ Johannes Holtfreter, 'Address in honor of Viktor Hamburger', in Michael Locke (ed.), The Emergence of Order in Developing Systems, New York: Academic Press, 1968, pp. viii-xvii, xi; one of the first uses: Dale Purves and Jeff W. Lichtman, Principles of Neural Development, Sunderland, MA: Sinauer, 1985, p. 140.

${ }^{70}$ Claudio D. Stern and Phil W. Ingham, preface to Stern and Ingham (eds.), Gastrulation, Development (1992) supplement. 
rejected theoretical biology: 'The greatest progressive minds of embryology have not searched for hypotheses; they have looked at embryos'. ${ }^{71}$ Morrill's poster had tempered any animosity towards theorizing by associating Wolpert with a striking picture (there was also the film), and it was a saving grace that, as he said, "My skill is to persuade other people to do experiments. ${ }^{72}$

The trickier issue was that, as Slack discovered when Wolpert phoned, 'Lewis did not remember the dinner in Antwerp.' As a keen student of the ironies of fame, Slack has wondered if 'I should have left his name off and become famous myself'. Instead, slack had burnished his mentor's reputation, and only a few insiders have been aware of his co-authorship. ${ }^{73}$ Maybe because 'As Wolpert has emphasised' was a cryptic reference, some hesitated over the attribution until he acknowledged paternity, but the quotation gained ground as it captured more media and Wolpert began to use it himself. ${ }^{74}$

Wolpert spoke the phrase, though not as a quotation, in 'Genesis', an episode, about developmental biology, of Horizon, the leading science series on BBC television, first broadcast in January 1986 and shown (as 'How babies get made') on the US science flagship NOVA a year later. Seated in his office, Wolpert looks at the interviewer with a twinkle in his eye and says,

It's not birth, death or marriage which is the most important event in your life, but gastrulation; and it is a very important event in early development, because you get enormous changes in the location of cells in the early embryo, so they get put in the right place so that organs can then really begin to develop [Figure 5]. ${ }^{75}$

He had incorporated the claim into his performance, his playing the part of Lewis Wolpert, while going on not quite to take it back, but to offer a more specific account of importance. ${ }^{76}$

When putting his name to the words in print, Wolpert took a still more cautious, even conflicted, approach. In The Triumph of the Embryo (1991), his first book for a general audience, he wrote, 'I have been quoted as saying that it is not birth, marriage, or death, but gastrulation which is truly "the important event in your life." I interpret this extraordinary sentence as corroborating Slack's account. The distancing ('I have been quoted ...') seems to accept that slack mediated Wolpert's access to the original. Placing quotation marks around only the bit that slack recalls him uttering makes sense as an implicit acknowledgement that the rest had not been his. Wolpert nevertheless formally took ownership and so completed the making of the quotation by authenticating the attribution. Almost so as to assert independence, he omitted 'most' and substituted 'event' for the more resonant 'time' (the Horizon variation was even

\footnotetext{
${ }^{71}$ Jane M. Oppenheimer, 'Problems, concepts and their history', in Benjamin H. Willier, Paul A. Weiss and Viktor Hamburger (eds.), Analysis of Development, Philadelphia: Saunders, 1955, pp. 1-24, 22.

${ }^{72}$ Smith, 'From engineering', op. cit. (21), p. 88.

${ }^{73}$ Slack to the author, 2 February 2021; Slack, op. cit. (2), which tells the Antwerp story on pp. 80-1, but leaves his own embellishment implicit.

74 'Wolpert is alleged to have stated': C.D. Stern and D.R. Canning, 'Gastrulation in birds: a model system for the study of animal morphogenesis', Experientia (1988) 44, pp. 651-7, 651; 'widely believed to have said': Steven B. Oppenheimer, 'The sea urchin embryo: a remarkable classroom tool', American Biology Teacher (1989) 51, pp. 354-7, 354.

75 'Genesis', op. cit. (67), 9:18-9:35. A preamble to the effect 'I have been quoted as saying ...' could have been edited out.

${ }^{76}$ For Wolpert the performer: Smith, 'From engineering', op. cit. (21), p. 90.
} 


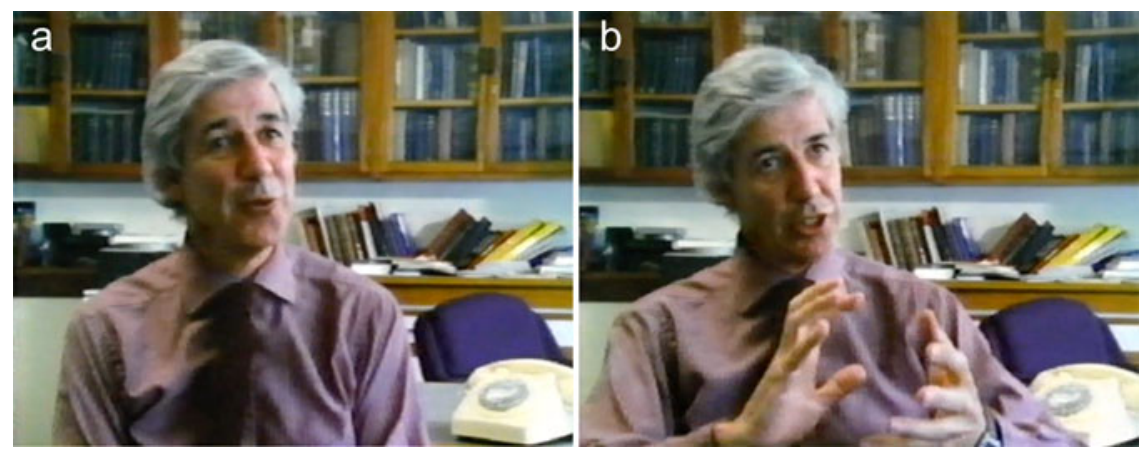

Figure 5. Wolpert interviewed by Jon Palfreman in late 1985 for 'Genesis', a BBC Horizon episode written and produced by Palfreman for a first broadcast on 13 January 1986. Screen captures show Wolpert (a) smilingly claiming the importance of gastrulation, and (b) using his hands to explain what it is.

freer), but Slack's has remained the version of record, and in practice the main elements are enough. ${ }^{77}$

Yet no sooner had Wolpert taken possession than he again rowed back. As if he had been told that the claim was '[e]xcessive', he proceeded to excuse it as 'the attempt to convince the clinician of the importance of studying early development'. He wrote with deliberate moderation around the same time, 'Gastrulation can be thought of as one of the most important processes in early development' - a statement it is hard to imagine on a poster. ${ }^{78}$ The reference to having been quoted and some kind of apology remained constants in his handling of the quotation, but by June 1996 he was presenting himself as having originated the whole phrase, which 'I am reported to have said, in a moment of apparent passion'. ${ }^{79}$ Others' assumptions that it was all his, grounded in Slack's crediting him, presumably made it too hard to sustain the subtle acknowledgement of their respective contributions - if that is what those quotation marks were.

That September the British Society for Developmental Biology (BSDB) honoured Wolpert with a meeting on The Molecular Basis of Positional Information, which Slack hosted at the University of Bath. After the conference dinner, attendees assembled in the Senior Common Room for a cabaret, written by Wolpert's collaborator Cheryll Tickle and head-and-neck expert Peter Thorogood, and based on Wolpert's sayings, including 'Morphogenesis is like origami' and 'To find out whether a transgenic mouse is really normal, you should take it to the opera, ${ }^{80}$ That there were several indicates how Wolpert's speaking and writing resonated and perhaps that quips stuck to him.

\footnotetext{
${ }^{77}$ Wolpert, op. cit. (37), p. 12. The quotation has sometimes been credited, following an influential student text, to the dubious source 'Wolpert 1986'. My analysis is informed by Morson, op. cit. (5), Chapters 3-7, though this case is somewhat different, including in that anthologies have yet to have much effect.

${ }^{78}$ Wolpert, op. cit. (37), p. 12; L. Wolpert, 'Gastrulation and the evolution of development', Development (1992) supplement, pp. 7-13, 12.

${ }^{79}$ Lewis Wolpert, 'Something fishy going on', Independent on Sunday, 2 June 1996, 'Sunday review', p. 50.

80 Tickle to the author, 17, 25 February 2021; 'Final programme', in BSDB meeting programmes (1996); Imelda Mc[G]onnell, 'Meeting report: “The molecular basis of positional information”', BSDB Newsletter (Autumn 1996) 34, pp. 2-3, both at http://bsdb.org/about-us/bsdb-newsletters. The origami analogy adapted one in Wolpert, op. cit. (37), p. 17, which built on Waddington, op. cit. (24), p. 40; the saying addressing the problem of non-phenotype knockout mice has been quoted without reference as 'But did you take it to the opera?' and in another version from Lewis Wolpert, Alain Ghysen and Antonio García-Bellido, 'Debatable issues', International Journal of Developmental Biology (1998) 42, pp. 511-19, 516.
} 


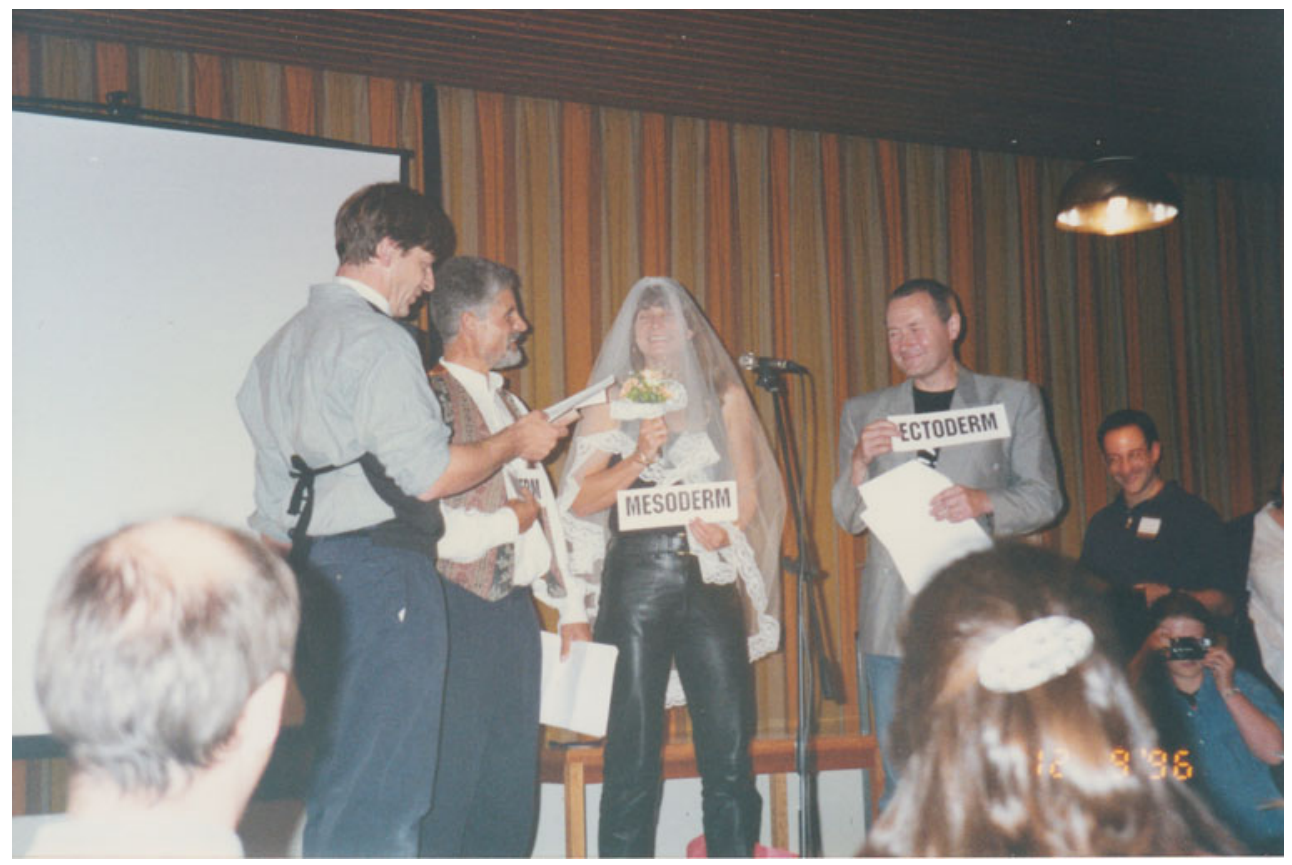

Figure 6. The marriage scene in the cabaret sketch on the gastrulation quotation at the Bath meeting on positional information, with (from left to right) Phil Ingham (priest), Jonathan Cooke (endoderm), Elizabeth Jones (mesoderm), Peter Thorogood (ectoderm), Martin Cohn and Katherine Robertson (with camera). Photo, I2 September 1996, by Imelda McGonnell.

The gastrulation quotation inspired the third sketch. Three developmental biologists, Thorogood, Jonathan Cooke and Paul Sharpe, each walked to the front of the stage and said, 'Happy gastrulation' before all singing 'Happy gastrulation to you' ('dear embryo') to the tune of 'Happy birthday' on piano and clarinet. Thorogood and Cooke displayed their labels, 'ectoderm' and 'endoderm' respectively; Sharpe moved right as a bystander. The priest, Phil Ingham (who read theology at Cambridge before switching to genetics), entered left with dog collar and prayer book, while 'Here comes the bride' played in the mesoderm, a veil-wearing Elizabeth Jones, who walked from the back to stand between the other germ layers (Figure 6). Then came a parody of the wedding service from the Book of Common Prayer, shorn of religious elements:

Priest $\quad$... We are gathered here today to witness the marriage of mesoderm, endoderm and ectoderm.

Do you mesoderm take this ectoderm and endoderm to form a gastrula forsaking all others for as long as you all shall live?

Mesoderm ... I do

Priest $\quad$... Do you ectoderm and endoderm take this mesoderm to form a gastrula forsaking all others for as long as you all shall live?

Ectoderm and endoderm

... We do

Priest $\quad$... If anyone here present, knows of any impediment why these three tissue layers may not be joined together to form a gastrula, let her now speak or forever hold her peace.

I now pronounce you a gastrula. 
To wedding bells, the germ layers processed off together. Malcolm Maden arrived and read from a newspaper a spoof of the marriage reports in The Times:

The gastrulation took place on Thursday [S]eptember 12th ... The mother of the gastrula was at a conference in Bath ... the father was even more unaware of the event ... the reception was held in the uterus. After the reception, the happy gastrula left for a honey moon in FRANCE ... and then started on neurulation and progressed to organogenesis.

'FRANCE' cued Sharpe to wave a flag for the 'French flag theory'. The priest announced 'Rest in peace gastrula' - that stage had died as the embryo developed and made the sign of the cross. With Maden and Sharpe, he intoned the quotation again. ${ }^{81}$ Now more than ever, Wolpert, who sat 'on the front row laughing', was wedded to all the words, which were personalized in a rumour that he 'made that remark after his divorce'. ${ }^{82}$

Wolpert's rising public profile as a combative commentator on science spread the quotation. Richard Dawkins has used the 'famous bon mot' in at least three books. ${ }^{83}$ In 2002, Wolpert expanded a bit on the origin story of his 'pretentious' remark, adding that a 'friend ... wrote it down, and it was made into a large poster with a lovely picture of a gastrulating embryo, which adorns my kitchen door' (Figure 3). ${ }^{84} \mathrm{~A}$ few years later, a Times interview reported the admission, 'Yes, it's [a] bit pompous, but we South Africans are not class-ridden like the English, so we actually say what we think ... I was just so irritated at this doctor not knowing what gastrulation was. ${ }^{85}$ When Wolpert died, the quotation was the most famous thing about him. It featured in numerous tweets (it is eminently tweetable), as well as the first paragraph of the Guardian obituary and the first slide of the biographical introduction to the inaugural memorial lecture. ${ }^{86}$

\section{Exposition and identification, juxtaposition and in-joke}

By juxtaposing a technical term with major life events the statement invites students and laypeople to conquer their ignorance. Like superimposing ' $e=m c^{2}$ ' on photos of the atom bomb or double helices on Adam and Eve, it claims significance by associating an abstruse topic with things that clearly matter. ${ }^{87}$

\footnotetext{
81 'Programme for cabaret', Cheryll Tickle papers, ellipses in original. A gendered reading suggests itself: the one woman starred as the mesoderm, which by invaginating takes the penetrative part that biologists traditionally coded as male, and entered into a bigamous marriage. Neither Tickle nor Jones recalled any such interpretations, though Tickle wrote that 'maybe it does say something about my view of males playing supporting roles': Tickle to the author, 13 May; Jones to the author, 10 May 2021.

${ }^{82}$ Laughter: Jones to the author, 9 May 2021; Scott Gilbert was told the rumour: Gilbert to the author, 3 April 2021.

${ }^{83}$ Richard Dawkins, River out of Eden: A Darwinian View of Life, London: Weidenfeld \& Nicolson, 1995, pp. 25-6; Dawkins, The Ancestor's Tale: A Pilgrimage to the Dawn of Evolution, Boston: Houghton Mifflin, 2004, p. 377; Dawkins, The Greatest Show on Earth: The Evidence for Evolution, New York: Free Press, 2009, p. 226 (quotation).

${ }^{84}$ Lewis Wolpert, 'How does an embryo tell its brain from its bottom? Sea urchins have the answer', The Independent, 6 May 2002, 'Review', p. 15.

${ }^{85}$ Anjana Ahuja, 'The trillions of little miracles inside us all', The Times, 28 March 2009, 'Saturday review', p. 5.

${ }^{86}$ Ferry, op. cit. (1); Claudio Stern, introduction to Lewis Wolpert Memorial Lecture, 20 May 2021, available at www.youtube.com/watch?v=vCfkeSuFyb8, 5:03-7:39.

${ }^{87}$ E.g. Time magazine covers for 1 July 1946 and 3 March 2003. Visual quotations are another large topic. On technicality: Theodore M. Porter, 'How science became technical', Isis (2009) 100, pp. 292-309.
} 
Teachers deployed the catchy slogan to tempt students to follow the embryonic origami. Scott Gilbert's Developmental Biology, establishing itself as the leading textbook, introduced the claim in the second (1988) edition as one of the epigraphs through which Gilbert, who was trained in history of science, gave temporal depth to the field. ${ }^{88}$ A later edition drove home the point in a note:

Keep in mind the warning of gastrulation researcher Ray Keller (personal communication): 'Students should NOT read this material quickly, but too typical a scene is some poor bastard hunkered over this text at 2:30 AM with a cup of coffee, frantically scanning the figures to see if he or she can work out what is happening.' Gastrulation is (as Wolpert says in the quotation at the beginning of this chapter) the most important time in your life. It is worth the time to examine it critically and to appreciate it at your leisure. ${ }^{89}$

US educators tended to present gastrulation as an individual achievement. 'Without this process', biology teachers were warned, 'many organisms would be round little balls that could never amount to anything'. ${ }^{90}$ A college biology text opened the chapter on animal development with the saying and went on,

Events that you might consider to be the most important in your life - such as graduating from high school or college, getting married, getting your first job, having a child, or [more optimistically] winning the Nobel prize - Wolpert finds trivial in comparison to gastrulation. What, you may ask, is gastrulation? ${ }^{91}$

Originally formulated in response to that question, the quotation, 'to most people, incomprehensible', invites readers and listeners to pose it again and again. ${ }^{92}$

By the early twenty-first century, no undergraduate course on development was complete without a slide of the sentence. During the COVID-19 pandemic, Salah Elias, a lecturer at the University of Southampton, tweeted, 'Today I missed students' [awed] reaction to Lewis Wolpert quote ... \#TeachingFromHome. ${ }^{93}$ Some may find it nerdy, they may groan, but it is the absolute value of the response that counts. ${ }^{94}$ The claim lures journalists for similar reasons: by linking a term that would hardly sell newspapers to birth and marriage, it lets subeditors write headlines like 'Birth? Trivial next to cellular doughnut-making process'. ${ }^{95}$

${ }^{88}$ Gilbert, op. cit. (67), p. 112.

${ }^{89}$ Scott F. Gilbert, Developmental Biology, 5th edn, Sunderland, MA: Sinauer, 1997, p. 210.

${ }^{90}$ Oppenheimer, op. cit. (74), p. 354.

${ }^{91}$ Willam K. Purves, Gordon H. Orians, H. Craig Heller and David Sadava, Life: The Science of Biology, 5th edn, Sunderland, MA: Sinauer, 1998, p. 883.

92 Quotation: Wolpert, op. cit. (84).

${ }^{93}$ Salah Elias (@theeliaslab), 30 April 2020, 11:16, https://twitter.com/theeliaslab/status/1255803191855284225; for the reaction: Elias, op. cit. (1).

${ }^{94}$ Scott F. Gilbert, 'Bacchus in the laboratory: in defense of scientific puns', Perspectives in Biology and Medicine (1985) 29, pp. 148-52, 152; Gilbert to the author, 3 April 2021: 'I think the students remember that quotation'; Ragkousi to the author, 1 March 2021: 'Students usually laugh and realize how scientists are often passionate about the problem they are working on and use over-dramatized language to communicate this.'

95 James Gorman, New York Times, 4 May 2015, www.nytimes.com/2015/05/04/science/birth-trivial-next-tocellular-doughnut-making-process.html. This case was typical, in that the researchers had used the quotation first, but unusual, in that they wrote from a maths department and made it the first sentence of the journal article: Stephanie Höhn, Aurelia R. Honerkamp-Smith, Pierre A. Haas, Philipp Khuc Trong and Raymond E. Goldstein, 'Dynamics of a Volvox embryo turning itself inside out', Physical Review Letters (2015) 114, 178101. 
The quotation has given teachers a mission comparable to that of the nineteenth-century embryologists who told classically educated sceptics that humans come from eggs. ${ }^{96}$ That few people have heard of gastrulation, and almost none could define it confidently, feeds the professional pride of those who can, while experts still debate what exactly it is. ${ }^{97}$ Now a lecturer at King's College London, Rita Sousa-Nunes came across the words on a slide that Wolpert showed in Portugal in the late 1990s. Then, 'Having chosen a PhD on gastrulation, I amused myself by baffling others with his famous quote'. ${ }^{88}$ 'Though most people wouldn't know what "gastrulation" was they would ask and I could explain succinctly."99

Once readers or listeners have learned the answer, the sentence becomes an in-joke, by emphasizing, as Slack put it, "the irony of "the most important time" being already over before you were aware of anything'. ${ }^{100}$ For Sousa-Nunes, the surprise 'makes us consider whether the dictum is true or not, and thus ... the importance of gastrulation'. ${ }^{101}$ The motto has been ubiquitous not just on the ageing posters that welcome some scientists into labs, and watch over them there, but wherever they stand back from the detail. ${ }^{102}$ Space is usually at too much of a premium in primary research articles, but even in research seminars, it never seems to pale. Inevitably, it advertised the Virtual Gastrulation Zoom Talks that ran during the pandemic. ${ }^{103}$ Developmental biologists identify with it - it reminds them why they do what they do - so it works, in different ways, for fellow researchers and for their audiences in lectures and press releases.

\section{Serious uses for 'a bit of fun'}

The quotation constantly meets new ears and eyes in established venues and genres, and circulates along fresh routes, without being so successful that everyone already knows about gastrulation. ${ }^{104}$ It has kept an unrivalled position also because it is not taken too seriously but highlights a process that has become politically as well as intellectually strategic.

\footnotetext{
${ }^{96}$ Hopwood, op. cit. (17), esp. Chapters 3, 8.

${ }^{97}$ Benjamin Steventon, Lara Busby and Alfonso Martinez Arias, 'Establishment of the vertebrate body plan: rethinking gastrulation through stem cell models of early embryogenesis', Developmental Cell (2021) 56, pp. 2405-18.

${ }_{98}$ Sousa-Nunes to the author, 17, 18 March 2021; quotation: Sousa-Nunes in 'Memories of Lewis Wolpert from current members of the BSDB committee', BSDB, 29 January 2021, http://bsdb.org/2021/01/29/memories-oflewis-wolpert-from-current-members-of-the-bsdb-committee.

${ }^{99}$ Sousa-Nunes to the author, 17 March 2021.

${ }^{100}$ Slack to the author, 2 February 2021.

${ }^{101}$ Sousa-Nunes to the author, 17 March 2021.

102 Sandra Acosta (@sacostav), 'For years, coming in to Oliver's lab to work, was welcomed by ... Wolpert's famous urchin gastrula ..., 28 January 2021, 22:31, https://twitter.com/sacostav/status/1354920050646519814. Guillermo Oliver (then at St Jude Children's Research Hospital in Memphis, TN) appeared with Morrill's poster and the comment 'A perfect statement to highlight the global impact of developmental biology' in a video, 'Why I choose development', SDB, www.sdbonline.org/whyichoosedevelopment, 12:39-12:50 (last updated 5 May 2017).

${ }^{103}$ Virtual Gastrulation Zoom Talks (@VGZT2020_21), ‘As Lewis Wolpert said ..., 1 December 2020, 10:53, https://twitter.com/VGZT2020_21/status/1333725974089887744; use (by Alice Vickers) on a slide in a lab meeting: Christina Philippeos (@DrChrissy_P), 'It's not birth ..., 8 December 2017, 11:41, https://twitter.com/ DrChrissy_P/status/939097647478116352?cxt=HHwWgMC09baVrIgaAAAA. Although no editor or referee objected, Nature's tight word limit forced the cutting of a first-sentence invocation of Wolpert's quip (present in the preprint at bioRxiv, https://doi.org/10.1101/421701) during revision of Stefan Münster, Akanksha Jain, Alexander Mietke, Anastasios Pavlopoulos, Stephan W. Grill and Pavel Tomancak, 'Attachment of the blastoderm to the vitelline envelope affects gastrulation of insects', Nature (2019) 568, pp. 395-9. The senior author 'fought for it ... but in the end, it was just a gimmick and ... had to go. At least I sometimes use it in my talks': Tomancak to the author, 19 November 2021.

${ }^{104}$ On one occasion, Sousa-Nunes, then still a Catholic, was shocked at mass in Mill Hill, London, to hear a priest refer to Jesus' gastrulation: Sousa-Nunes to the author, 17, 18 March 2021.
} 
In the face of criticism - 'excessive', 'pretentious' and 'pompous' were Wolpert's own words - the aphorism could always be defended as 'just a bit of fun', and its pithy power has put at a disadvantage those advocating for other developmental stages. ${ }^{105}$ In 1986 , colleagues from his own lab argued, tongue in cheek, 'While one can hardly mistake childbirth, and while half the world has been known to stop for a wedding, gastrulation is neither obvious nor dramatic for the onlooker. The real show stopping events are ... neurulation and segmentation which produce recognisable living organisms from a featureless surface'. Two years later, at a meeting in Madrid, another Londoner, Jonathan Cooke, defended his view that the mesoderm is patterned before gastrulation by protesting,

Lewis, we go all around the world seeing the poster with a beautiful scanning electron micrograph of a sea urchin gastrulating and a quote from you that 'it isn't when you are born or when you are married that counts, it is when you gastrulate'. Well, I have to tell you that even by that stage, it is largely all over bar the shouting! ${ }^{106}$

Some have pointed out that, among placental mammals, 'If implantation fails, so does gastrulation'. ${ }^{107}$ Implantation is often said to be 'the most crucial' time in IVF, 'because this is ... where you are actually getting pregnant! ${ }^{108}$ With resources at stake, the argument is pushed still further back, but given the high rate of initial wastage, the ability of young mammalian embryos to recover from damage, and the (contested) assumption that all kinds of embryo converge on a gastrula stage, it has made sense to spotlight a process that is early but not too early. ${ }^{109}$ The success of the quotation represents, in part, a victory of gastrulation over fertilization.

In the 1980s, when mammalian developmental biologists campaigned for the research on human preimplantation embryos that IVF had opened up, the quotation was shielded from those controversies (and use in debating abortion remains rare). ${ }^{110}$ It has still benefited from researchers' increasing insistence that, since establishing even a new genetic identity is long-drawn-out, fertilization 'simply initiates another step in the refining process that leads to the establishment of individuality'. ${ }^{111}$ In the United Kingdom, the mouse

\footnotetext{
105 'Bit of fun': Slack to the author, 2 February 2021.

${ }^{106}$ Dennis Summerbell, Helen Coetzee and Amata Hornbruch, 'A unique population of non-dividing cells in the somites', in Ruth Bellairs, Donald A. Ede and James W. Lash (eds.), Somites in Developing Embryos, New York: Plenum, 1986, pp. 105-17, 105; Jonathan Cooke, 'Induction and the organization of the body plan in Xenopus development', in David Evered and Joan Marsh (eds.), Cellular Basis of Morphogenesis, Chichester: Wiley, 1989, pp. 187-207, 204. For metamorphosis as 'an equally important time of life' in flies: David Lee Osterbur, 'Ecdysteroid action in Drosophila melanogaster: receptors and genes', PhD dissertation, University of California, Berkeley, May 1986, p. 43.

107 Ann Sutherland, 'Mechanisms of implantation in the mouse: differentiation and functional importance of trophoblast giant cell behavior', Developmental Biology (2003) 258, pp. 241-51, 241.

${ }^{108}$ Dara Duff-Bergeron, '2 weeks pregnant: getting pregnant and charting menstrual cycle', Everything Mom, 24 March 2019, www.everythingmom.com/pregancy/pregnancy-calendar/2-weeks-pregnant-getting-pregnant-andcharting-menstrual-cycle.

${ }^{109}$ Claims, against Wolpert's dictum, for preimplantation development: Magdalena Zernicka-Goetz, 'Patterning of the embryo: the first spatial decisions in the life of a mouse', Development (2002) 129, pp. 815-29, 816; Nicole Rusk, 'Seeing heterochromatin in early embryos', Nature Methods (2013) 10, p. 1143; Tom P. Fleming, Judith J. Eckert and Oleg Denisenko, 'The role of maternal nutrition during the periconceptional period and its effect on offspring phenotype', in Alireza Fazeli and William V. Holt (eds.), Periconception in Physiology and Medicine, Cham: Springer, 2017, pp. 87-105, abstract.

${ }^{110}$ But see Scott F. Gilbert, 'Republicans need to be countered on false claims about embryos', HuffPost, 9 September 2015, www.huffpost.com/entry/countering-republican-claims-embryos_b_8152028.

${ }^{111}$ Peter R. Braude and Martin H. Johnson, 'The embryo in contemporary medical science', in G.R. Dunstan (ed.), The Human Embryo: Aristotle and the Arabic and European Traditions, Exeter: University of Exeter Press, 1990, pp. 208-21, 211; Johnson, 'Did I begin?', New Scientist (9 December 1989) 124(1694), pp. 39-42.
} 
developmental geneticist Anne McLaren persuaded fellow members of Mary Warnock's Committee of Inquiry into Human Fertilization and Embryology to compromise on the formation of the primitive streak as an arbitrary boundary that had some meaning because, with twinning then no longer possible, it marks 'when I began being me'. The UK Human Fertilization and Embryology Act 1990 enshrined this fourteen-day threshold in law and many other jurisdictions follow the same rule. The appearance of the streak signals the start of gastrulation, but those endorsing the research did not much use that word. ${ }^{112}$

More recently, concerted studies of gene expression in embryos and fetuses obtained from terminations of pregnancy, and then also in vitro models derived from stem cells, joined continued culturing of preimplantation embryos donated from IVF programmes to make 'human developmental biology'. ${ }^{113}$ This subfield admitted 'gastrulation' as a term and began to use the quotation to spur self-knowledge. In 2016, when spare IVF embryos were grown beyond the stage of implantation and close to the legal limit, a Sunday newspaper used Wolpert's words to drive home how much there was to do (Figure 7). The awardwinning former science editor of The Independent Steve Connor argued in the left-liberal Observer that 'no one has ... witnessed gastrulation in a human embryo'; it could only be inferred from other mammals and old microscope slides. Yet 'Wolpert was right - this is where the real business of development starts', Connor reported Azim Surani, the authority on the human germline, as saying. Researchers promised 'deeper understanding' and 'medical benefits' from extending the limit. ${ }^{114}$ The argument was no longer that research on humans should stop, in effect, at gastrulation, in part because it is a significant stage, but that gastrulation is so fundamental that it demands further investigation, and that, if we are to learn what makes us human, this will have to be of human embryos. The maxim has, though, been used also to rationalize and celebrate the main work-arounds: research on mice and on human stem cell models. ${ }^{115}$

The quotation will likely stay current not just because teachers still need a spoonful of sugar to help the medicine go down, and research is lively on gastrulation and on human embryos, but also because developmental biology is seeking more generally to justify itself. Around the year 2000, after two heady decades of discovery, practitioners worried that their discipline was losing itself in details, expected now to deliver on promises of clinical payoffs, and suffering competition from the upstart stem cell field. Developmental biologists have been looking for ways to promote their science. ${ }^{116}$ One is tried and tested and already in wide use.

\footnotetext{
112 Anne McLaren, 'Where to draw the line?' Journal of the Royal Institution of Great Britain (1984) 56, pp. 101-21, 112; McLaren, 'Why study early human development?', New Scientist (24 April 1986) 110(1505), pp. 49-52; further: Sarah Franklin, 'Developmental landmarks and the Warnock report: a sociological account of biological translation', Comparative Studies in Society and History (2019) 61, pp. 743-73.

${ }^{113}$ A landmark volume: T. Strachan, S. Lindsay and D.I. Wilson (eds.), Molecular Genetics of Early Human Development, Oxford: BIOS Scientific Publishers, 1997; on a tissue bank: Susan Lindsay and Andrew J. Copp, 'MRC-Wellcome Trust Human Developmental Biology Resource: enabling studies of human developmental gene expression', Trends in Genetics (2005) 21, pp. 586-90; an editorial on 'the emergence of this new field': Olivier Pourquié, Benoit Bruneau, Gordon Keller and Austin Smith, 'Looking inwards: opening a window onto human development', Development (2015) 142, pp. 1-2.

${ }^{114}$ Steve Connor, 'Inside the "black box" of human development', The Observer, 5 June 2016, www.theguardian. com/science/2016/jun/05/human-development-ivf-embryos-14-day-legal-limit-extend-inside-black-box.

${ }^{115}$ Mice: 'Establishing the molecular blueprint of early embryo development', Wellcome-MRC Cambridge Stem Cell Institute, 20 February 2019, www.stemcells.cam.ac.uk/news/molecularblueprint; stem cells: Marta N. Shahbazi, 'Mechanisms of human embryo development: from cell fate to tissue shape and back', Development (2020) 147, dev190629, p. 7.

${ }^{116}$ Hopwood, 'Inclusion and exclusion', op. cit. (31), p. 5.
} 


\title{
The Observer \\ Embryos \\ Inside the 'black box' of human development
}

\begin{abstract}
Researchers will soon have the means to study embryos beyond the 14-day legal limit. Does the potential for advances in medicine outweight ethical concerns?
\end{abstract}

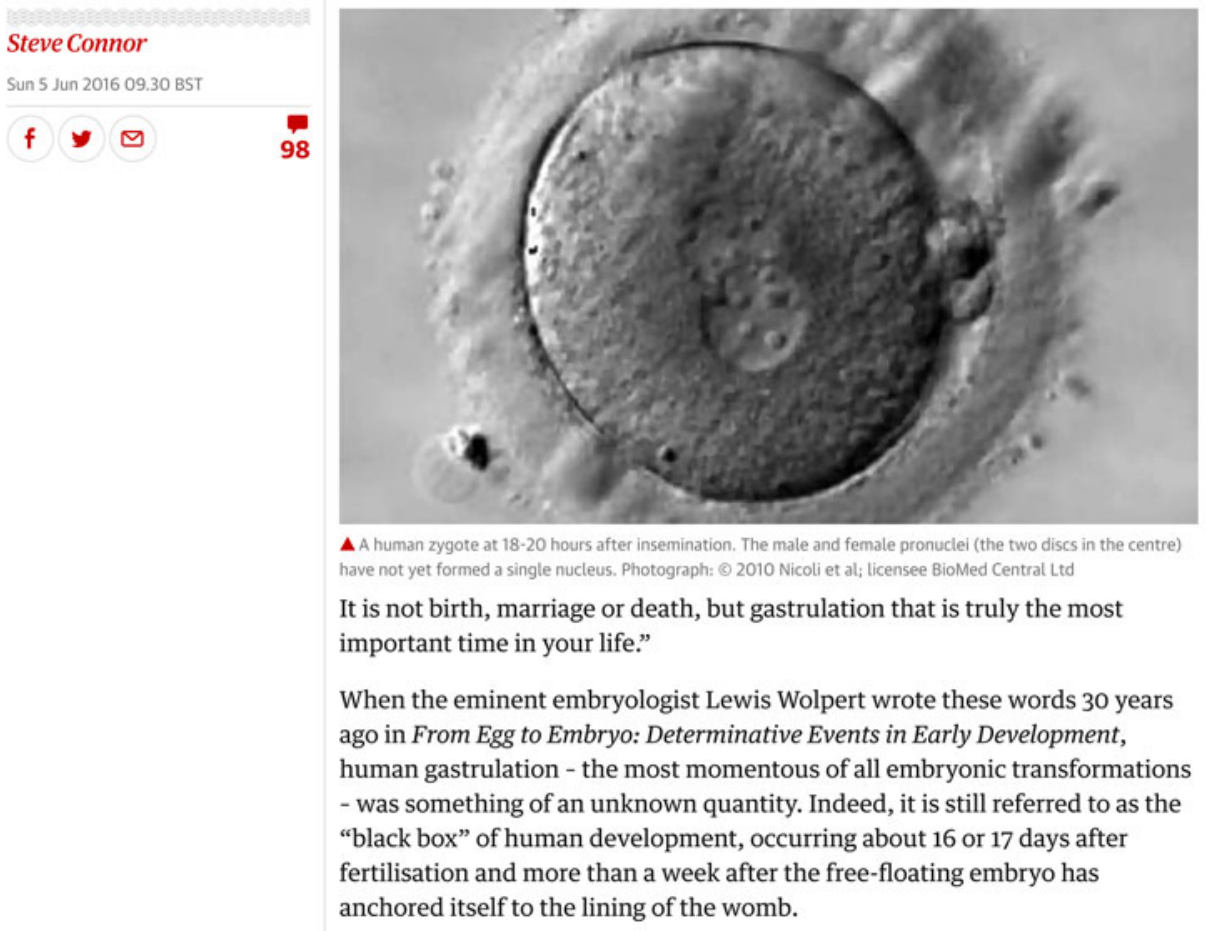

Figure 7. The quotation as the first paragraph of an Observer story about pressure to extend the fourteen-day limit on human-embryo research. Wolpert is taken to have written the words in From Egg to Embryo. Steve Connor, 'Inside the "black box" of human development', The Observer, 5 June 2016, www.theguardian.com/science/2016/jun/05/ human-development-ivf-embryos-I4-day-legal-limit-extend-inside-black-box. () Guardian News \& Media Ltd 2021.

\section{Conclusion}

Quotations may be luxuries for scientists, but are affordable enough to have led active lives. Beyond after-dinner speeches and anthologies, they shape teaching and research even in recent sciences, and function as public faces of disciplines, complete in this case with the attempt to domesticate a technical term. Honed and hallowed, the words lend confidence and clout when vying for attention and conveying a sense of fun, pointing to problems and claiming resources. Invoking tradition, they generate a feeling of belonging, honour previous generations and inspire the next.

Though initiated by, thrust upon and embraced by one researcher as it drew on and enhanced his authority, a community assembled Wolpert's dictum. Following general claims for the importance of prenatal life, embryologists had begun, with Haeckel in the late nineteenth century, to underline fertilization and occasionally gastrulation. In persuading larger audiences that a more detailed embryology mattered, they highlighted not just the start of embryogenesis, but also that somewhat later event. As so often, having to justify a specialist 
topic in conversation sparked a witty riposte that sieved antecedents. Transfer to print polished a statement now designed to recruit to a field and a problem, inviting responses that made a quotation and amplified it in one medium after another. Similar practices of persuasion, remediation, elaboration, attribution, selection and amplification have created and conferred special status on other vivid short texts.

If '[w]e are what we quote', successful quotations embody and reveal community values. ${ }^{117}$ This one encapsulated the interests and ethos of late twentieth-century developmental biology: the concern with laying down the body plan, the recognition of early plasticity and the continuity of life, the focus on model organisms and distance from a human embryology that banned the word 'gastrulation', the decoupling from the hottest issues of reproductive politics. As the field has changed, so human developmental biologists have made the saying implicate more clearly our own species. Appealing through rhetorical juxtaposition and as an in-joke, it is to a remarkable degree both part of the expository toolkit and a marker of professional identity. Not all scientific quotations have starred in such varied roles, though many have played more than one, and some have done different work. Once you look, it becomes hard to imagine science without them.

Acknowledgements. I am most grateful to those who generously shared recollections and advice: Jonathan Slack, Cheryll Tickle, Jim Smith, Laurinda Santos, Scott Gilbert, Rita Sousa-Nunes, Katerina Ragkousi, Kenneth Manning, Dmitriy Myelnikov, Alfonso Martinez Arias, Elizabeth Jones, Gary Wessel, Joshua Waxman, Deborah Hursh, Randall Moon, William Jeffery, Richard Showman, Roger Sawyer, Gary Schoenwolf, Pavel Tomancak, Jon Palfreman, Rosalind Grooms, Drew Noden and Ida Chow. For finding and providing materials, including some heroic efforts, I am indebted to Cheryll Tickle, Imelda McGonnell, Neil Vargesson, Ana McGrath (New College of Florida), Willem Vanneste (Universiteitsarchief Antwerpen), Peter Ponsaerts (Belgian Society for Cell and Developmental Biology), Ans Spaepen (Rijksarchief Antwerpen), Lindsey Loeper (Center for Biological Sciences Archives) and Lewis Held. I thank Ian Bolton and Adrian Newman (Anatomy Visual Media Group) for preparing the figures and the BSHS Online Conference in July 2021 for feedback. Jim Secord helped me to realize the potential of the piece, and Silvia De Renzi, Susanne Schmidt and Jenny Bangham to sharpen it up.

${ }^{117}$ Quotation: Morson, op. cit. (5), p. 38.

Cite this article: Hopwood N (2022). 'Not birth, marriage or death, but gastrulation': the life of a quotation in biology. The British Journal for the History of Science 55, 1-26. https://doi.org/10.1017/S0007087421000790 